\title{
Cancer as a metabolic disease
}

\author{
Thomas N Seyfried*, Laura M Shelton
}

\begin{abstract}
Emerging evidence indicates that impaired cellular energy metabolism is the defining characteristic of nearly all cancers regardless of cellular or tissue origin. In contrast to normal cells, which derive most of their usable energy from oxidative phosphorylation, most cancer cells become heavily dependent on substrate level phosphorylation to meet energy demands. Evidence is reviewed supporting a general hypothesis that genomic instability and essentially all hallmarks of cancer, including aerobic glycolysis (Warburg effect), can be linked to impaired mitochondrial function and energy metabolism. A view of cancer as primarily a metabolic disease will impact approaches to cancer management and prevention.
\end{abstract}

\section{Introduction}

Cancer is a complex disease involving numerous tempospatial changes in cell physiology, which ultimately lead to malignant tumors. Abnormal cell growth (neoplasia) is the biological endpoint of the disease. Tumor cell invasion of surrounding tissues and distant organs is the primary cause of morbidity and mortality for most cancer patients. The biological process by which normal cells are transformed into malignant cancer cells has been the subject of a large research effort in the biomedical sciences for many decades. Despite this research effort, cures or long-term management strategies for metastatic cancer are as challenging today as they were 40 years ago when President Richard Nixon declared a war on cancer $[1,2]$.

Confusion surrounds the origin of cancer. Contradictions and paradoxes have plagued the field [3-6]. Without a clear idea on cancer origins, it becomes difficult to formulate a clear strategy for effective management. Although very specific processes underlie malignant transformation, a large number of unspecific influences can initiate the disease including radiation, chemicals, viruses, inflammation, etc. Indeed, it appears that prolonged exposure to almost any provocative agent in the environment can potentially cause cancer $[7,8]$. That a very specific process could be initiated in very unspecific ways was considered "the oncogenic paradox" by SzentGyorgyi [8]. This paradox has remained largely unresolved [7].

\footnotetext{
* Correspondence: thomas.seyfried@bc.edu

Biology Department, Boston College, Chestnut Hill, MA 02467, USA
}

In a landmark review, Hanahan and Weinberg suggested that six essential alterations in cell physiology could underlie malignant cell growth [6]. These six alterations were described as the hallmarks of nearly all cancers and included, 1) self-sufficiency in growth signals, 2) insensitivity to growth inhibitory (antigrowth) signals, 3) evasion of programmed cell death (apoptosis), 4) limitless replicative potential, 5) sustained vascularity (angiogenesis), and 6) tissue invasion and metastasis. Genome instability, leading to increased mutability, was considered the essential enabling characteristic for manifesting the six hallmarks [6]. However, the mutation rate for most genes is low making it unlikely that the numerous pathogenic mutations found in cancer cells would occur sporadically within a normal human lifespan [7]. This then created another paradox. If mutations are such rare events, then how is it possible that cancer cells express so many different types and kinds of mutations?

The loss of genomic "caretakers" or "guardians", involved in sensing and repairing DNA damage, was proposed to explain the increased mutability of tumor cells $[7,9]$. The loss of these caretaker systems would allow genomic instability thus enabling pre-malignant cells to reach the six essential hallmarks of cancer [6]. It has been difficult, however, to define with certainty the origin of pre-malignancy and the mechanisms by which the caretaker/guardian systems themselves are lost during the emergent malignant state [5,7].

In addition to the six recognized hallmarks of cancer, aerobic glycolysis or the Warburg effect is also a robust metabolic hallmark of most tumors [10-14]. Although 
no specific gene mutation or chromosomal abnormality is common to all cancers [7,15-17], nearly all cancers express aerobic glycolysis, regardless of their tissue or cellular origin. Aerobic glycolysis in cancer cells involves elevated glucose uptake with lactic acid production in the presence of oxygen. This metabolic phenotype is the basis for tumor imaging using labeled glucose analogues and has become an important diagnostic tool for cancer detection and management [18-20]. Genes for glycolysis are overexpressed in the majority of cancers examined $[21,22]$.

The origin of the Warburg effect in tumor cells has been controversial. The discoverer of this phenomenon, Otto Warburg, initially proposed that aerobic glycolysis was an epiphenomenon of a more fundamental problem in cancer cell physiology, i.e., impaired or damaged respiration $[23,24]$. An increased glycolytic flux was viewed as an essential compensatory mechanism of energy production in order to maintain the viability of tumor cells. Although aerobic glycolysis and anaerobic glycolysis are similar in that lactic acid is produced under both situations, aerobic glycolysis can arise in tumor cells from damaged respiration whereas anaerobic glycolysis arises from the absence of oxygen. As oxygen will reduce anaerobic glycolysis and lactic acid production in most normal cells (Pasteur effect), the continued production of lactic acid in the presence of oxygen can represent an abnormal Pasteur effect. This is the situation in most tumor cells. Only those body cells able to increase glycolysis during intermittent respiratory damage were considered capable of forming cancers [24]. Cells unable to elevate glycolysis in response to respiratory insults, on the other hand, would perish due to energy failure. Cancer cells would therefore arise from normal body cells through a gradual and irreversible damage to their respiratory capacity. Aerobic glycolysis, arising from damaged respiration, is the single most common phenotype found in cancer.

Based on metabolic data collected from numerous animal and human tumor samples, Warburg proposed with considerable certainty and insight that irreversible damage to respiration was the prime cause of cancer [23-25]. Warburg's theory, however, was attacked as being too simplistic and not consistent with evidence of apparent normal respiratory function in some tumor cells [26-34]. The theory did not address the role of tumor-associated mutations, the phenomenon of metastasis, nor did it link the molecular mechanisms of uncontrolled cell growth directly to impaired respiration. Indeed, Warburg's biographer, Hans Krebs, mentioned that Warburg's idea on the primary cause of cancer, i.e., the replacement of respiration by fermentation (glycolysis), was only a symptom of cancer and not the cause [35]. The primary cause was assumed to be at the level of gene expression. The view of cancer as a metabolic disease was gradually displaced with the view of cancer as a genetic disease. While there is renewed interest in the energy metabolism of cancer cells, it is widely thought that the Warburg effect and the metabolic defects expressed in cancer cells arise primarily from genomic mutability selected during tumor progression [36-39]. Emerging evidence, however, questions the genetic origin of cancer and suggests that cancer is primarily a metabolic disease.

Our goal is to revisit the argument of tumor cell origin and to provide a general hypothesis that genomic mutability and essentially all hallmarks of cancer, including the Warburg effect, can be linked to impaired respiration and energy metabolism. In brief, damage to cellular respiration precedes and underlies the genome instability that accompanies tumor development. Once established, genome instability contributes to further respiratory impairment, genome mutability, and tumor progression. In other words, effects become causes. This hypothesis is based on evidence that nuclear genome integrity is largely dependent on mitochondrial energy homeostasis and that all cells require a constant level of useable energy to maintain viability. While Warburg recognized the centrality of impaired respiration in the origin of cancer, he did not link this phenomenon to what are now recognize as the hallmarks of cancer. We review evidence that make these linkages and expand Warburg's ideas on how impaired energy metabolism can be exploited for tumor management and prevention.

\section{Energetics of the living cell}

In order for cells to remain viable and to perform their genetically programmed functions they must produce usable energy. This energy is commonly stored in ATP and is released during the hydrolysis of the terminal phosphate bond. This is generally referred to as the free energy of ATP hydrolysis [40-42]. The standard energy of ATP hydrolysis under physiological conditions is known as $\Delta G^{\prime}{ }_{\mathbf{A T P}}$ and is tightly regulated in all cells between -53 to $-60 \mathrm{~kJ} / \mathrm{mol}$ [43]. Most of this energy is used to power ionic membrane pumps $[10,40]$. In cells with functional mitochondria, this energy is derived mostly from oxidative phosphorylation where approximately $88 \%$ of total cellular energy is produced (about 28/32 total ATP molecules). The other approximate $12 \%$ of energy is produced about equally from substrate level phosphorylation through glycolysis in the cytoplasm and through the TCA cycle in the mitochondrial matrix (2 ATP molecules each). Veech and co-workers showed that the $\Delta G_{\text {ATP }}$ of cells was empirically formalized and measurable through the energies of ion distributions via the sodium pump and its linked transporters [42]. The energies of ion distributions were explained in 
terms of the Gibbs-Donnan equilibrium, which was essential for producing electrical, concentration, and pressure work.

A remarkable finding was the similarity of the $\Delta \mathrm{G}_{\text {ATP }}$ among cells with widely differing resting membrane potentials and mechanisms of energy production. For example, the $\Delta \mathrm{G}_{\mathrm{ATP}}{ }_{\mathrm{T}}$ in heart, liver, and erythrocytes was approximately - $56 \mathrm{~kJ} / \mathrm{mol}$ despite having very different electrical potentials of - 86, - 56, and $-6 \mathrm{mV}$, respectively [42]. Moreover, energy production in heart and liver, which contain many mitochondria, is largely through respiration, whereas energy production in the erythrocyte, which contains no nucleus or mitochondria, is entirely through glycolysis. Warburg also showed that the total energy production in quiescent kidney and liver cells was remarkably similar to that produced in proliferating cancer cells [24]. Despite the profound differences in resting potentials and in mechanisms of energy production among these disparate cell types, they all require a similar amount of total energy to remain viable.

The constancy of the $\Delta \mathrm{G}_{\mathrm{ATP}}$ of approximately $-56 \mathrm{~kJ} /$ mol is fundamental to cellular homeostasis and its relationship to cancer cell energy is pivotal. The maintenance of the $\Delta G_{\text {ATP }}$ is the "end point" of both genetic and metabolic processes and any disturbance in this energy level will compromise cell function and viability [40]. Cells can die from either too little or too much energy. Too little energy will lead to cell death by either necrotic or apoptotic mechanisms, whereas over production of ATP, a polyanionic Donnan active material, will disrupt the Gibbs-Donnan equilibrium, alter the function of membrane pumps, and inhibit respiration and viability [42]. Glycolysis or glutaminolysis must increase in cells suffering mitochondrial impairment in order to maintain an adequate $\Delta G^{\prime}{ }_{\text {ATP }}$ for viability. This fact was clearly illustrated in showing that total cellular energy production was essentially the same in respiration-normal and respiration-deficient fibroblasts [44].

In addition to its role in replenishing TCA cycle intermediates (anaplerosis), glutamine can also provide energy through stimulation of glycolysis in the cytoplasm and through substrate level phosphorylation in the TCA cycle (glutaminolysis) [45-49]. Energy obtained through substrate level phosphorylation in the TCA cycle can compensate for deficiencies in either glycolysis or oxidative phosphorylation $[46,48,50]$, and can represent a major source of energy for the glutamine-dependent cancers. More energy is produced through substrate level phosphorylation in cancer cells than in normal cells, which produce most of their energy through oxidative phosphorylation. A major difference between normal cells and cancer cells is in the origin of the energy produced rather than in the amount of energy produced since approximately $-56 \mathrm{~kJ} / \mathrm{mol}$ is the amount of energy required for cell survival regardless of whether cells are quiescent or proliferating or are mostly glycolytic or respiratory. It is important to recognize, however, that a prolonged reliance on substrate level phosphorylation for energy production produces genome instability, cellular disorder, and increased entropy, i.e., characteristics of cancer $[8,24]$.

\section{Mitochondrial function in cancer cells}

Considerable controversy has surrounded the issue of mitochondrial function in cancer cells [18,29,30,33,34,51-57]. Sidney Weinhouse and Britton Chance initiated much of this controversy through their critical evaluation of the Warburg theory and the role of mitochondrial function [33,34]. Basically, Weinhouse felt that quantitatively and qualitatively normal carbon and electron transport could occur in cancer cells despite the presence of elevated glycolysis [33,34]. Weinhouse assumed that oxygen consumption and $\mathrm{CO}_{2}$ production were indicative of coupled respiration. However, excessive amounts of Donnan active material (ATP) would be produced if elevated glycolysis were expressed together with coupled respiration [42]. Accumulation of Donnan active material will induce cell swelling and produce a physiological state beyond the Gibbs-Donnan equilibrium. The occurrence of up-regulated glycolysis together with normal coupled respiration is incompatible with metabolic homeostasis and cell viability. Chance and Hess also argued against impaired respiration in cancer based on their spectrophotometric studies showing mostly normal electron transfer in ascites tumor cells [58]. These studies, however, failed to assess the level of ATP production as a consequence of normal electron transfer and did not exclude the possibility of elevated ATP production through TCA cycle substrate level phosphorylation. As discussed below, mitochondrial uncoupling can give the false impression of functional respiratory capacity.

Oxygen uptake and $\mathrm{CO}_{2}$ production can occur in mitochondria that are uncoupled and/or dysfunctional $[24,59]$. While reduced oxygen uptake can be indicative of reduced oxidative phosphorylation, increased oxygen uptake may or may not be indicative of increased oxidative phosphorylation and ATP production [59-62]. Ramanathan and co-workers showed that oxygen consumption was greater, but oxygen dependent (aerobic) ATP synthesis was less in cells with greater tumorigenic potential than in cells with lower tumorigenic potential [61]. These findings are consistent with mitochondrial uncoupling in tumor cells. It was for these types of observations in other systems that Warburg considered the phenomenon of aerobic glycolysis as too capricious to serve as a reliable indicator of respiratory status [24]. 
Heat production is also greater in poorly differentiated high glycolytic tumor cells than in differentiated low glycolytic cells [63]. Heat production is consistent with mitochondrial uncoupling in these highly tumorigenic cells. Although Burk, Schade, Colowick and others convincingly dispelled the main criticisms of the Warburg theory $[55,57,64]$, citations to the older arguments for normal respiration in cancer cells persist in current discussions of the subject.

Besides glucose, glutamine can also serve as a major energy metabolite for some cancers [65-67]. Glutamine is often present in high concentrations in culture media and serum. Cell viability and growth can be maintained from energy generated through substrate level phosphorylation in the TCA cycle using glutamine as a substrate $[47,48]$. Energy obtained through this pathway could give the false impression of normal oxidative phosphorylation, as oxygen consumption and $\mathrm{CO}_{2}$ production can arise from glutaminolysis and uncoupled oxidative phosphorylation. Hence, evidence suggesting that mitochondrial function is normal in cancer cells should be considered with caution unless data are provided, which exclude substrate level phosphorylation through glutaminolysis or glycolysis as alternative sources of energy.

\section{Mitochondrial dysfunction in cancer cells}

Numerous studies show that tumor mitochondria are structurally and functionally abnormal and incapable of generating normal levels of energy $[10,60,61,68-74]$. Recent evidence also shows that the in vitro growth environment alters the lipid composition of mitochondrial membranes and electron transport chain function [75]. Moreover, the mitochondrial lipid abnormalities induced from the in vitro growth environment are different from the lipid abnormalities found between normal tissue and tumors that are grown in vivo. It appears that the in vitro growth environment reduces Complex I activity and obscures the boundaries of the Crabtree and the Warburg effects. The Crabtree effect involves the inhibition of respiration by high levels of glucose [76,77], whereas the Warburg effect involves inhibition of respiration from impaired oxidative phosphorylation. While the Crabtree effect is reversible, the Warburg effect is largely irreversible. Similarities in mitochondrial lipids found between lung epidermoid carcinoma and fetal lung cells are also consistent with respiratory defects in tumor cells [78]. The bioenergetic capacity of mitochondria is dependent to a large extent on the content and composition of mitochondrial lipids.

Alterations in mitochondrial membrane lipids and especially the inner membrane enriched lipid, cardiolipin, disrupt the mitochondrial proton motive gradient $\left(\Delta \Psi_{\mathrm{m}}\right)$ thus inducing protein-independent uncoupling with concomitant reduction in respiratory energy production [41,73,79-82]. Cancer cells contain abnormalities in cardiolipin content or composition, which are associated with electron transport abnormalities [73]. Cardiolipin is the only lipid synthesized almost exclusively in the mitochondria. Proteins of the electron transport chain evolved to function in close association with cardiolipin. Besides altering the function of most electron transport chain complexes including the F1-ATPase, abnormalities in cardiolipin content and composition can also inhibit uptake of ADP through the adenine nucleotide transporter thus altering the efficiency of oxidative phosphorylation $[41,79-81,83]$. Abnormalities in the content and composition of cardiolipin will also prevent oxidation of the coenzyme $\mathrm{Q}$ couple thus producing reactive oxygen species during tumor progression $[73,84]$. Increased ROS production can impair genome stability, tumor suppressor gene function, and control over cell proliferation $[7,85]$. Hence, abnormalities in CL can alter cancer cell respiration in numerous ways.

Cardiolipin abnormalities in cancer cells can arise from any number of unspecific influences to include damage from mutagens and carcinogens, radiation, low level hypoxia, inflammation, ROS, or from inherited mutations that alter mitochondrial energy homeostasis [73]. Considering the dynamic behavior of mitochondria involving regular fusions and fissions [86], abnormalities in mitochondrial lipid composition and especially of cardiolipin could be rapidly disseminated throughout the cellular mitochondrial network and could even be passed along to daughter cells somatically, through cytoplasmic inheritance.

Besides lipidomic evidence supporting the Warburg cancer theory [73], recent studies from Cuezva and colleagues also provide compelling proteomic evidence supporting the theory [21]. Their results showed a drop in the $\beta$-F1-ATPase/Hsp60 ratio concurrent with an upregulation of the glyceraldehyde-3-phosphate dehydrogenase potential in most common human tumors [72]. These and other observations indicate that the bioenergetic capacity of tumor cells is largely defective [87-89]. Viewed collectively, the bulk of the experimental evidence indicates that mitochondria structure and function is abnormal in cancer cells. Hence, mitochondrial dysfunction will cause cancer cells to rely more heavily than non-cancer cells on substrate level phosphorylation for energy production in order to maintain membrane pump function and cell viability.

\section{Linking genome instability to mitochondrial dysfunction}

Is it genomic instability or is it impaired energy metabolism that is primarily responsible for the origin of cancer? This is more than an academic question, as the answer will impact approaches to cancer management 
and prevention. Metabolic studies in a variety of human cancers previously showed that that loss of mitochondrial function preceded the appearance of malignancy and aerobic glycolysis [90]. However, the general view over the last 50 years has been that gene mutations and chromosomal abnormalities underlie most aspects of tumor initiation and progression including the Warburg effect and impaired respiratory function. The gene theory of cancer would argue that mitochondrial dysfunction is an effect rather than a cause of cancer, whereas the metabolic impairment theory would argue the reverse. If gene mutations are the primary cause of cancer then the disease can be considered etiologically complicated requiring multiple solutions for management and prevention. This comes from findings that the numbers and types of mutations differ markedly among and within different types of tumors. If, on the other hand, impaired energy metabolism is primarily responsible for cancer, then most cancers can be considered a type of metabolic disease requiring fewer and less complicated solutions.

Although mitochondrial function and oxidative phosphorylation is impaired in tumor cells, it remains unclear how these impairments relate to carcinogenesis and to the large number of somatic mutations and chromosomal abnormalities found in tumors [7,15,91-93]. Most inherited "inborn errors of metabolism" do not specifically compromise mitochondrial function or cause cancer in mammals. There are some exceptions, however, as germ-line mutations in genes encoding proteins of the TCA cycle can increase risk to certain human cancers [94]. For example, risk for paraganglioma involves mutations in the succinate dehydrogenase gene, whereas risk for leiomyomatosis and renal cell carcinoma involves mutations in the fumarate hydratase (fumarase) gene [94-97]. These and similar mutations directly impair mitochondrial energy production leading to increased glycolysis and the Warburg effect [98]. Although rare inherited mutations in the p53 tumor suppressor gene can increase risk for some familial cancers of the Li Fraumeni syndrome [99], most p53 defects found in cancers are not inherited and appear to arise sporadically, as do the vast majority of cancer-associated mutations $[6,7,100]$. In general, cancer-causing germline mutations are rare and contribute to only about $5-7 \%$ of all cancers [5,7]. While germline mutations can cause a few cancers, most cancer mutations are somatic and will contribute more to the progression than to the origin of most cancers.

The cancer mutator phenotype was invoked to explain the large number of somatic mutations found in cancer, but mutations in the p53 caretaker gene are not expressed in all cancers nor does p53 deletion produce cancer in mice suggesting a more complicated involvement of this and other genome guardians in carcinogenesis [7,101-104]. While numerous genetic abnormalities have been described in most human cancers, no specific mutation is reliably diagnostic for any specific type of tumor $[7,17,105]$. On the other hand, few if any tumors are known, which express normal respiration.

\section{Retrograde response and genomic instability}

As an alternative to the genome guardian hypothesis for the origin of somatic mutations, a persistent retrograde response can underlie the genomic instability and mutability of tumor cells. The retrograde (RTG) response is the general term for mitochondrial signaling and involves cellular responses to changes in the functional state of mitochondria [106-110]. Although the RTG response has been most studied in yeast, mitochondrial stress signaling is an analogous response in mammalian cells $[110,111]$. Expression of multiple nuclear genes controlling energy metabolism is profoundly altered following impairment in mitochondrial energy homeostasis $[112,113]$. Mitochondrial impairment can arise from abnormalities in mtDNA, the TCA cycle, the electron transport chain, or in the proton motive gradient $\left(\Delta \Psi_{\mathrm{m}}\right)$ of the inner membrane. Any impairment in mitochondrial energy production can trigger an RTG response. The RTG response evolved in yeast to maintain cell viability following periodic disruption of mitochondrial ATP production $[110,114]$. This mostly involves an energy transition from oxidative phosphorylation to substrate level phosphorylation. Similar systems are also expressed in mammalian cells [110-113]. Prolonged or continued activation of the retrograde response, however, can have dire consequences on nuclear genome stability and function.

Three main regulatory elements define the RTG response in yeast to include the Rtg2 signaling protein, and the Rtg1/Rtg-3 transcriptional factor complex (both are basic helix-loop-helix-leucine zippers) [110]. Rtg2 contains an N-terminal ATP binding motif that senses changes in mitochondrial ATP production. Rtg2 also regulates the function and cellular localization of the heterodimeric Rtg1/Rtg-3 complex (Figure 1). The RTG response is "off" in healthy cells with normal mitochondrial function. In the off state, the Rtg1/Rtg3 complex is sequestered in the cytoplasm with Rtg1 attached (dimerized) to a highly phosphorylated form of Rtg3 [110]. Besides its role in the cytoplasm as an energy sensor, Rtg2 also functions in the nucleus as a regulator of chromosomal integrity [115].

The RTG response is turned "on" following impairment in mitochondrial energy production. In the on state, cytoplasmic Rtg2 disengages the Rtg1/Rtg-3 complex through a dephosphorylation of Rtg3 [110]. The 


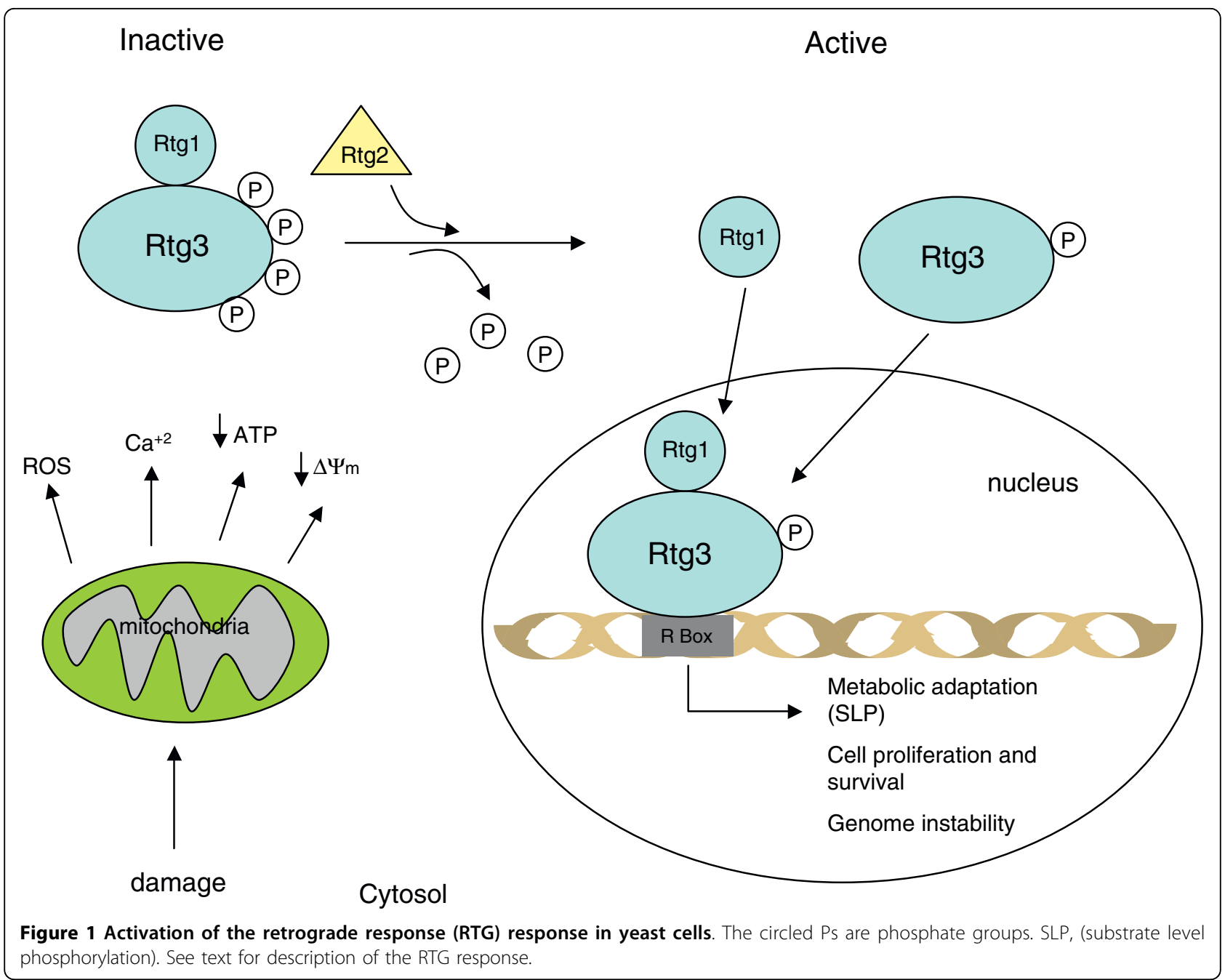

Rtg1 and Rtg3 proteins then individually enter the nucleus where $\mathrm{R} \operatorname{tg} 3$ binds to $\mathrm{R}$ box sites, $\mathrm{R} \operatorname{tg} 1$ reengages Rtg3, and transcription and signaling commences for multiple energy and anti-apoptotic related genes and proteins to include MYC, TOR, p53, Ras, CREB, NFkB, and CHOP [110,112,113,116-118]. The RTG response also involves the participation of multiple negative and positive regulators, which facilitate the bioenergetic transition from respiration to substrate level phosphorylation [110].

The primary role of the RTG response is to coordinate the synthesis of ATP through glycolysis alone or through a combination of glycolysis and glutaminolysis when respiratory function is impaired $[110,111]$. The RTG response would be essential for maintaining a stable $\Delta G_{\text {ATP }}$ for cell viability during periods when respiration is impaired. A prolonged RTG response, however, would leave the nuclear genome vulnerable to instability and mutability $[112,117,119]$. Mitochondrial dysfunction also increases levels of cytoplasmic calcium, the multi-drug resistance phenotype, production of reactive oxygen species, and abnormalities in iron-sulfur complexes, which together would further accelerate aberrant RTG signaling and genome mutability [85,106,107,110,111,120-122]. Chronic tissue inflammation could further damage mitochondria, which would accelerate these processes $[123,124]$. Considered collectively, these findings indicate that the integrity of the nuclear genome is dependent to a large extent on the functionality and energy production of the mitochondria.

\section{Similarities between yeast cells and mammalian cells to impaired respiration}

Interesting analogies exist between yeast and mammalian cells for the physiological response to impaired respiration [76,112,117,125,126]. Mammalian cells increase expression of hypoxia-inducible factor-1a (HIF$1 \alpha)$ in response to transient hypoxia [127]. HIF-1 $\alpha$ is rapidly degraded under normoxic conditions, but 
becomes stabilized under hypoxia. This is a conserved physiological response that evolved to protect mammalian mitochondria from hypoxic damage and to provide an alternative source of energy to respiration, as HIF- $1 \alpha$ induces expression of pyruvate dehydrogenase kinase 1 and most major genes involved with glucose uptake, glycolysis, and lactic acid production [127]. HIF-1 $\alpha$ expression is also elevated in most tumor cells whether or not hypoxia is present and could mediate in part aerobic glycolysis $[20,28,98,128,129]$. Although the mechanisms of HIF- $1 \alpha$ stabilization under hypoxic conditions are well defined, the mechanisms by which HIF-1 $\alpha$ is stabilized under aerobic or normoxic conditions are less clear $[129,130]$.

HIF- $1 \alpha$ is generally unstable in cells under normal aerobic conditions through its interaction with the von Hippel-Lindau (VHL) tumor suppressor protein, which facilitates HIF-1 $\alpha$ hydroxylation, ubiquitination, and proteasomal degradation [28]. HIF-1 $\alpha$ stabilization under aerobic conditions can be linked to mitochondrial dysfunction through abnormalities in calcium homeostasis, ROS generation, NFkB signaling, accumulation of TCA cycle metabolites (succinate and fumarate), and oncogenic viral infections [131-135]. It is not yet clear if genomic instability can arise through prolonged HIF- $1 \alpha$ stabilization under aerobic conditions as would occur during tumor initiation and progression.

Besides HIF- $1 \alpha$ function, the human MYC transcription factor also shows homology to the yeast Rtg3 transcription factor [112]. MYC is also a member of the basic, helix-loop-helix leucine zipper family of transcription factors as are RTG1 and RTG3. HIF- $1 \alpha$ and MYC also up-regulate many of the same genes for glycolysis [136]. Hence, both HIF- $1 \alpha$ and MYC share similarities with components of the yeast RTG system.

\section{Mitochondrial dysfunction and the mutator phenotype}

Most human cancer cells display genome instability involving elevated mutation rates, gross chromosomal rearrangements, and alterations in chromosome number $[15,17,100,137]$. The recent studies of the Singh and the Jazwinski groups provide compelling evidence that mitochondrial dysfunction, operating largely through the RTG response (mitochondrial stress signaling), can underlie the mutator phenotype of tumor cells $[71,113,115,117,138]$. Chromosomal instability, expression of gene mutations, and the tumorigenic phenotype were significantly greater in human cells with mtDNA depletion than in cells with normal mtDNA. Mitochondrial dysfunction can also down-regulate expression of the apurinic/apyrimidinic endonuclease APE1. This is a redox-sensitive multifunctional endonuclease that regulates DNA transcription and repair [113,139]. APE1 down regulation will increase genomic mutability. Since gene expression is different in different tissues, it is expected that disturbed energy metabolism would produce different kinds of mutations in different types of cancers. Even different tumors within the same cancer type could appear to represent different diseases when evaluated at the genomic level. When evaluated at the metabolic level, however, most cancers and tumors are alike in expressing mitochondrial dysfunction and elevated substrate level phosphorylation. Emerging evidence suggests that mitochondrial dysfunction underlies the mutator phenotype of tumor cells.

Impaired mitochondrial function can induce abnormalities in tumor suppressor genes and oncogenes. For example, impaired mitochondrial function can induce abnormalities in p53 activation, while abnormalities in p53 expression and regulation can further impair mitochondrial function $[85,103,113,116,140-143]$. The function of the $\mathrm{pRB}$ tumor suppressor protein, which controls the cell cycle, is also sensitive to ROS production through the redox state of the cell [144]. Elevated expression of the MYC and Ras oncogenes can be linked to the requirements of substrate level phosphorylation to maintain tumor cell viability. Hence, the numerous gene defects found in various cancers can arise as secondary consequences of mitochondrial dysfunction.

Calcium homeostasis is also dependent on mitochondrial function [110]. It appears that calcium homeostasis is essential for the fidelity of mitosis to include spindle assembly, sister chromosome separation, and cytokinesis [145-150]. Disturbances in cytoplasmic calcium homeostasis, arising as a consequence of mitochondrial dysfunction [111], could contribute to abnormalities in chromosomal segregation during mitosis. These findings suggest that the numerous chromosomal abnormalities found in cancer cells can arise as a consequence of mitochondrial damage.

Recent studies in yeast indicate that damage to the inner mitochondrial membrane potential $\left(\Delta \Psi_{\mathrm{m}}\right)$ following loss of mtDNA alters the function of several nuclear iron-sulfur-dependent DNA repair enzymes involving the Rad3 helicase, the Pri2 primase, and the Ntg2 glycase [107]. Abnormalities in these DNA repair enzymes contribute to the loss of heterozygosity ( $\mathrm{LOH}$ ) phenotype in specific genes of the affected yeast cells. These findings indicate that $\mathrm{LOH}$, which is commonly observed in many genes of cancer cells [100], can also be linked to mitochondrial dysfunction. Considered collectively, these observations suggest that the bulk of the genetic abnormalities found in cancer cells, ranging from point mutations to gross chromosomal rearrangements, can arise following damage to the structure and function of mitochondria.

Impairment of mitochondrial function can occur following prolonged injury or irritation to tissues including 
disruption of morphogenetic fields [123,151]. This tumorigenic process could be initiated in the cells of any tissue capable of producing mitochondrial stress signaling following repetitive sub-lethal respiratory damage over prolonged periods. The accumulation of mitochondrial damage over time is what ultimately leads to malignant tumor formation. Acquired abnormalities in mitochondrial function would produce a type of vicious cycle where impaired mitochondrial energy production initiates genome instability and mutability, which then accelerates mitochondrial dysfunction and energy impairment and so on in a cumulative way. An increased dependency on substrate level phosphorylation for survival would follow each round of metabolic and genetic damage thus initiating uncontrolled cell growth and eventual formation of a malignant neoplasm. In other words, the well-documented tumor-associated abnormalities in oncogenes, tumor suppressor genes, and chromosomal imbalances can arise as a consequence of the progressive impairment of mitochondrial function.

\section{Mitochondrial dysfunction following viral infection}

Viruses have long been recognized as the cause of some cancers [152]. It is interesting that several cancer-associated viruses localize to, or accumulate in, the mitochondria. Viral alteration of mitochondrial function could potentially disrupt energy metabolism thus altering expression of tumor suppressor genes and oncogenes over time. Viruses that can affect mitochondrial function include the Rous sarcoma virus, Epstein-Barr virus (EBV), Kaposi's sarcoma-associated herpes virus (KSHV), human papilloma virus (HPV), hepatitis B virus (HBV), hepatitis $\mathrm{C}$ virus (HCV), and human T-cell leukemia virus type 1 (HTLV-1) [64,153-155]. Although viral disruption of mitochondrial function will kill most cells through apoptosis following an acute infection, those infected cells that can up-regulate substrate level phosphorylation will survive and potentially produce a neoplasm following chronic infection. Indeed, the hepatitis $\mathrm{B} \times$ protein $(\mathrm{HBx})$ blocks HIF-1 $\alpha$ ubiquitination thus increasing HIF- $1 \alpha$ stability and activity in a hypoxia-independent manner [135]. Alterations in calcium homeostasis, ROS production, and expression of NF-kB and HIF- $1 \alpha$ are also expected to alter the metabolic state as was previously found for some viral infections [153,154]. It is interesting in this regard that carcinogenesis, whether arising from viral infection or from chemical agent, produces similar impairment in respiratory enzyme activity and mitochondrial function [90]. Thus, viruses can potentially cause cancer through displacement of respiration with substrate level phosphorylation in the infected cells. Alterations in expression of tumor suppressor genes and oncogenes will follow this energy transformation according to the general hypothesis presented here.

\section{Mitochondrial suppression of tumorigenicity}

While the mutator phenotype of cancer can be linked to impaired mitochondrial function, normal mitochondrial function can also suppress tumorigenesis. It is well documented that tumorigenicity can be suppressed when cytoplasm from enucleated normal cells is fused with tumor cells to form cybrids, suggesting that normal mitochondria can suppress the tumorigenic phenotype [156-158]. Singh and co-workers provided additional evidence for the role of mitochondria in the suppression of tumorigenicity by showing that exogenous transfer of wild type mitochondria to cells with depleted mitochondria $\left(\mathrm{rho}^{0}\right.$ cells) could reverse the altered expression of the APE1 multifunctional protein and the tumorigenic phenotype [113]. On the other hand, introduction of mitochondrial mutations can reverse the anti-tumorigenic effect of normal mitochondria in cybrids [159]. It is also well documented that nuclei from cancer cells can be reprogrammed to form normal tissues when transplanted into normal cytoplasm despite the continued presence of the tumor-associated genomic defects in the cells of the derived tissues [160-162]. These findings indicate that nuclear gene mutations alone cannot account for the origin of cancer and further highlight the dynamic role of mitochondria in the epigenetic regulation of carcinogenesis.

It is expected that the presence of normal mitochondria in tumor cells would restore the cellular redox status, turn off the RTG response, and reduce or eliminate the need for glycolysis (Warburg effect) and glutaminolysis to maintain viability. In other words, normal mitochondrial function would facilitate expression of the differentiated state thereby suppressing the tumorigenic or undifferentiated state. This concept can link mitochondrial function to the long-standing controversy on cellular differentiation and tumorigenicity $[5,163]$. Respiration is required for the emergence and maintenance of differentiation, while loss of respiration leads to glycolysis, dedifferentiation, and unbridled proliferation $[8,25]$. These observations are consistent with the general hypothesis presented here, that prolonged impairment of mitochondrial energy metabolism underlies carcinogenesis. New studies are necessary to assess the degree to which cellular energy balance is restored in cybrids and in reprogrammed tumor cells.

\section{Linking the acquired capabilities of cancer to impaired energy metabolism}

Although the mutator phenotype was considered the essential enabling characteristic for manifesting the six hallmarks of cancer, the pathways by which the acquired 
capabilities of cancer are linked specifically to impaired energy metabolism remain poorly defined. Kromer and Pouyssegur recently provided an overview on how the hallmarks of cancer could be linked to signaling cascades and to the metabolic reprogramming of cancer cells [164]. As the acquired capabilities of self-sufficiency in growth signals, insensitivity to growth inhibitory (antigrowth) signals, and limitless replicative potential are similar, these capabilities can be grouped and discussed together. The acquired capabilities of evasion of programmed cell death, angiogenesis, and metastasis can be discussed separately.

\section{Growth signaling abnormalities and limitless replicative potential}

A central concept in linking abnormalities of growth signaling and replicative potential to impaired energy metabolism is in recognizing that proliferation rather than quiescence is the default state of both microorganisms and metazoans $[5,8,165,166]$. The cellular default state is the condition under which cells are found when they are freed from any active control. Respiring cells in mature organ systems are quiescent largely because their replicative potential is under negative control through the action of tumor suppressor genes like p53 and the retinoblastoma protein, pRB [144,165]. As p53 function is linked to cellular respiration, prolonged damage to respiration will gradually reduce p 53 function thus inactivating the negative control of p53 and of other tumor suppressor genes on cell proliferation.

A persistent impairment in respiratory function will trigger the RTG response, which is necessary for up-regulating the pathways of glycolysis and glutaminolysis in order to maintain the $\Delta G^{\prime}{ }_{\text {ATP }}$ for viability. The RTG response will activate MYC, Ras, HIF-1 $\alpha$, Akt, and mTor etc, which are required to facilitate and to sustain up-regulation of substrate level phosphorylation $[61,110,113,167,168]$. In addition to facilitating the uptake and metabolism of alternative energy substrates through substrate level phosphorylation, MYC and Ras further stimulate cell proliferation $[136,169,170]$. Part of this mechanism also includes inactivation of $\mathrm{pRB}$, the function of which is dependent on mitochondrial activities and the cellular redox state [144]. Disruption of the pRB signaling pathway will contribute to cell proliferation and neoplasia [6]. Hence, the growth signaling abnormalities and limitless replicative potential of tumor cells can be linked directly to the requirements of glycolysis and glutaminolysis and ultimately to impaired respiration.

It is interesting that RTG signaling also underlies replicative life span extension in budding yeast. Yeast longevity is manifested by the number of buds that a mother cell produces before it dies [110]. The greater the loss of mitochondrial function, the greater is the induction of the RTG response, and the greater the longevity (bud production) [108]. As mitochondrial function declines with age, substrate level phosphorylation becomes necessary to compensate for the lost energy from respiration if a cell is to remain alive. A greater reliance on substrate level phosphorylation will induce oncogene expression and unbridled proliferation, which could underlie in part the enhanced longevity in yeast $[110,112,119]$. When this process occurs in mammalian cells, however, the phenomenon is referred to as neoplasia or "new growth". We propose that replicative life span extension in yeast and limitless replicative potential in tumor cells can be linked through common bioenergetic mechanisms involving impaired mitochondrial function.

\section{Linking telomerase to mitochondrial function}

Emerging evidence indicates that telomerase, a ribonucleoprotein complex, plays a role in tumor progression [171]. Although still somewhat sparse, data suggest that mitochondrial dysfunction could underlie the relocation of telomerase from the mitochondria, where it seems to have a protective role, to the nucleus where it maintains telomere integrity necessary for limitless replicative potential [172-174]. Interestingly, telomerase activity is high during early embryonic development when anaerobic glycolysis and cell proliferation is high, but telomerase expression is suppressed in adult tissues, where cellular energy is derived largely from respiration. Further studies will be necessary to determine how changes in telomerase expression and subcellular localization could be related to mitochondrial dysfunction, elevated substrate level phosphorylation, and to the limitless replication of tumor cells.

\section{Evasion of programmed cell death (apoptosis)}

Apoptosis is a coordinated process that initiates cell death following a variety of cellular insults. Damage to mitochondrial energy production is one type of insult that can trigger the apoptotic cascade, which ultimately involves release of mitochondrial cytochrome c, activation of intracellular caspases, and death [6]. In contrast to normal cells, acquired resistance to apoptosis is a hallmark of most types of cancer cells [6]. The evasion of apoptosis is a predictable physiological response of tumor cells that up-regulate substrate level phosphorylation for energy production following respiratory damage during the protracted process of carcinogenesis. Only those cells capable of making the gradual energy transition from respiration to substrate level phosphorylation in response to respiratory damage will be able to evade apoptosis. Cells unable to make this energy transition will die and thus never become tumor cells. 
Numerous findings indicate that the genes and signaling pathways needed to up-regulate and sustain substrate level phosphorylation are themselves antiapoptotic. For example, sustained glycolysis requires participation of mTOR, MYC, Ras, HIF- $1 \alpha$, and the IGF-1/PI3K/Akt signaling pathways $[28,110,112,113,128,168]$. The up-regulation of these genes and pathways together with inactivation of tumor suppressor genes like p53, which is required to initiate apoptosis, will disengage the apoptotic-signaling cascade thus preventing programmed cell death [142].

Abnormalities in the mitochondrial membrane potential $\left(\Delta \Psi_{\mathrm{m}}\right)$ can also induce expression of known antiapoptotic genes $\left(\mathrm{Bcl} 2\right.$ and $\left.\mathrm{Ccl}-\mathrm{X}_{\mathrm{L}}\right)$ [111]. Tumor cells will continue to evade apoptosis as long as they have access to glucose and glutamine, which are required to maintain substrate level phosphorylation. Glycolytic tumor cells, however, can readily express a robust apoptotic phenotype if their glucose supply is targeted. This was clearly illustrated in experimental brain tumors using calorie restriction $[168,175,176]$. Hence, the evasion of apoptosis in tumor cells can be linked directly to a dependency on substrate level phosphorylation, which itself is a consequence of impaired respiratory function.

\section{Sustained vascularity (angiogenesis)}

Angiogenesis involves neovascularization or the formation of new capillaries from existing blood vessels and is associated with the processes of tissue inflammation, wound healing, and tumorigenesis [123,124,177,178]. Angiogenesis is required for most tumors to grow beyond an approximate size of 0.2-2.0 mm [179]. Vascularity is necessary in order to provide the tumor with essential energy nutrients to include glucose and glutamine, and to remove toxic tumor waste products such as lactic acid and ammonia [49]. In addition to its role in up-regulating glycolysis in response to hypoxia, HIF$1 \alpha$ is also the main transcription factor for vascular endothelial growth factor (VEGF), which stimulates angiogenesis [168,180-182]. HIF-1 $\alpha$ is part of the IGF-1/ PI3K/Akt signaling pathway that also indirectly influences expression of $\beta$ FGF, another key angiogenesis growth factor $[168,183]$. Hence the sustained vascularity of tumors can be linked mechanistically to the metabolic requirements of substrate level phosphorylation necessary for tumor cell survival.

\section{Invasion and metastasis}

Metastasis is the general term used to describe the spread of cancer cells from the primary tumor to surrounding tissues and to distant organs and is a primary cause of cancer morbidity and mortality $[6,184,185]$. Metastasis involves a complex series of sequential and interrelated steps. In order to complete the metastatic cascade, cancer cells must detach from the primary tumor, intravasate into the circulation and lymphatic system, evade immune attack, extravasate at a distant capillary bed, and invade and proliferate in distant organs [185-189]. Metastatic cells also establish a microenvironment that facilitates angiogenesis and proliferation, resulting in macroscopic, malignant secondary tumors. A difficulty in better characterizing the molecular mechanisms of metastasis comes in large part from the lack of animal models that manifest all steps of the cascade. Tumor cells that are naturally metastatic should not require intravenous injection in animal models to initiate the metastatic phenotype $[190,191]$. In vitro models, on the other hand, do not replicate all the steps required for systemic metastasis in vivo. Although the major steps of metastasis are well documented, the process by which metastatic cells arise from within populations of non-metastatic cells of the primary tumor is largely unknown [185,192,193].

Several mechanisms have been advanced to account for the origin of metastasis. The epithelial-mesenchymal transition (EMT) posits that metastatic cells arise from epithelial cells through a step-wise accumulation of gene mutations that eventually transform an epithelial cell into a tumor cell with mesenchymal features [6,100,194-196]. The idea comes from findings that many cancers generally arise in epithelial tissues where abnormalities in cell-cell and cell-matrix interactions occur during tumor progression. Eventually neoplastic cells emerge that appear as mesenchymal cells, which lack cell-cell adhesion and are dysmorphic in shape [185]. These transformed epithelial cells eventually acquire the multiple effector mechanisms of metastasis [185]. Recent studies suggest that ectopic co-expression of only two genes might be all that is necessary to facilitate EMT in some gliomas [197]. Considerable controversy surrounds the EMT hypothesis of metastasis, however, as EMT is not often detected in tumor pathological preparations $[198,199]$.

The macrophage hypothesis of metastasis suggests that metastatic cells arise following fusions of macrophages or bone marrow derived hematopoietic cells with committed tumor cells $[193,200,201]$. It is well documented that metastatic cancer cells, arising from a variety of tissues, possess numerous properties of macrophages or cells of myeloid lineage including phagocytosis and fusogenicity [190,202-208]. Macrophages and other types of myeloid cells are already genetically programmed to enter and exit tissues. Many of the normal behaviors of macrophages elaborate each step of the metastatic cascade [204]. Fusion of a myeloid cell (macrophage) with a tumor cell could produce a hybrid cell possessing the replicative capacity of the tumor cell and the properties of macrophages including the 
invasive and inflammatory properties [193,205,209]. As myeloid cells are also part of the immune system, evasion of immune surveillance would be another expected characteristic of metastatic cells derived from macrophage-like cells [205]. Indeed, metastatic melanoma cells can phagocytose live T-cells, which are supposed to kill the tumor cells [210].

Fusions among metastatic myeloid cells at the primary tumor site could, through reprogramming strategies, also produce functional epithelial cells at secondary sites potentially simulating the histological characteristics of the original tissue of origin $[200,211,212]$. The macrophage fusion hypothesis would also fit with the roles of hematopoietic stem cells in the metastatic niche $[208,213]$. While the fusion hypothesis is attractive, it would be an exception to the observations showing suppressed tumorigenicity following hybridization between normal cells and tumor cells [163], though some exceptions have been reported [205,206]. However, neither the EMT hypothesis nor the macrophage fusion hypothesis link the origin of metastasis to the Warburg effect or to impaired energy metabolism.

Recent findings of cardiolipin abnormalities in systemic metastatic mouse tumor cells with macrophage properties can link metastasis to impaired respiratory function in these cells $[73,190,204]$. Most tissues contain resident phagocytes as part of their histoarchitecture or stroma [214]. Tumor associated macrophages (TAM) also become a major cell type in many cancers [215]. While TAM can facilitate the invasive and metastatic properties of tumor cells $[213,216]$, metastatic tumor cells can also express several properties of TAM [190,204].

Damage to the respiratory capacity of resident tissue phagocytes, TAM, or macrophage hybrids would trigger a RTG response, force a reliance on substrate level phosphorylation for energy, and eventually, over time, lead to dysregulated growth and genomic instability as described in the general hypothesis. Metastatic behavior would be an expected outcome following impaired respiratory function in hematopoietic or myeloid-type cells, as macrophages are already mesenchymal cells that embody the capacity to degrade the extracellular matrix, to enter and to exit tissues from the blood stream, to migrate through tissues, and to survive in hypoxic environments. A sampling of human metastatic cancers with properties of macrophage-like cells include brain [204,217-220], breast [221-225], lung [202,225-229], skin [203,205,209,210,230-233], gastric [234], colon [235,236], pancreas [237,238], bladder [239], kidney [240], ovarian [241,242], and muscle [243,244]. It is important to mention that these macrophage properties are expressed in the tumor cells themselves and are not to be confused with similar properties expressed in the non-neoplastic TAM, which are also present in tumors and can facilitate tumor progression $[190,213,215,216,245]$. Poor prognosis is generally associated with those cancers that display characteristics of macrophages [210,221]. Hence, damage to the respiratory capacity of myeloid or macrophage-like cells would produce "rogue macrophages" leading to cancers with the highest metastatic behavior.

The plethora of the cell surface molecules thought to participate in metastatic tumor cell behavior are also expressed on myeloid cells especially macrophages $[185,213]$. A robust Warburg effect in human metastatic lesions, detected with combined ${ }^{18} \mathrm{~F}$-fluorodeoxyglucosepositron emission tomography imaging, indicates that metastatic cells have impaired energy metabolism like that of most cancer cells $[18,20,246]$. Hence, invasion and metastasis can be linked to impaired energy metabolism if this impairment occurs in cells of hematopoietic or myeloid origin.

\section{Connecting the links}

The path from normal cell physiology to malignant behavior, where all major cancer hallmarks are expressed, is depicted in Figure 2 and is based on the evidence reviewed above. Any unspecific condition that damages a cell's oxidative phosphorylation, but is not severe enough to induce apoptosis, can potentially initiate the path to a malignant cancer. Some of the many unspecific conditions contributing to carcinogenesis can include inflammation, carcinogens, radiation (ionizing or ultraviolet), intermittent hypoxia, rare germline mutations, viral infections, and disruption of tissue morphogenetic fields. Any of these conditions can damage the structure and function of mitochondria thus activating a specific RTG response in the damaged cell. If the mitochondrial damage persists, the RTG response will persist. Uncorrected mitochondrial damage will require a continuous compensatory energy response involving substrate level phosphorylation in order to maintain the $\Delta \mathrm{G}_{\text {ATP }}$ of approximately $-56 \mathrm{~kJ} / \mathrm{mol}$ for cell viability. Tumor progression is linked to a greater dependence on substrate level phosphorylation, which eventually becomes irreversible. As the integrity of the nuclear genome is dependent on the efficiency of mitochondrial energy production, the continued impairment of mitochondrial energy production will gradually undermine nuclear genome integrity leading to a mutator phenotype and a plethora of somatic mutations. Activation of oncogenes, inactivation of tumor suppressor genes, and aneuploidy will be the consequence of protracted mitochondrial dysfunction. These gene abnormalities will contribute further to mitochondrial dysfunction while also enhancing those energy pathways needed to up-regulate and sustain substrate level phosphorylation. The 


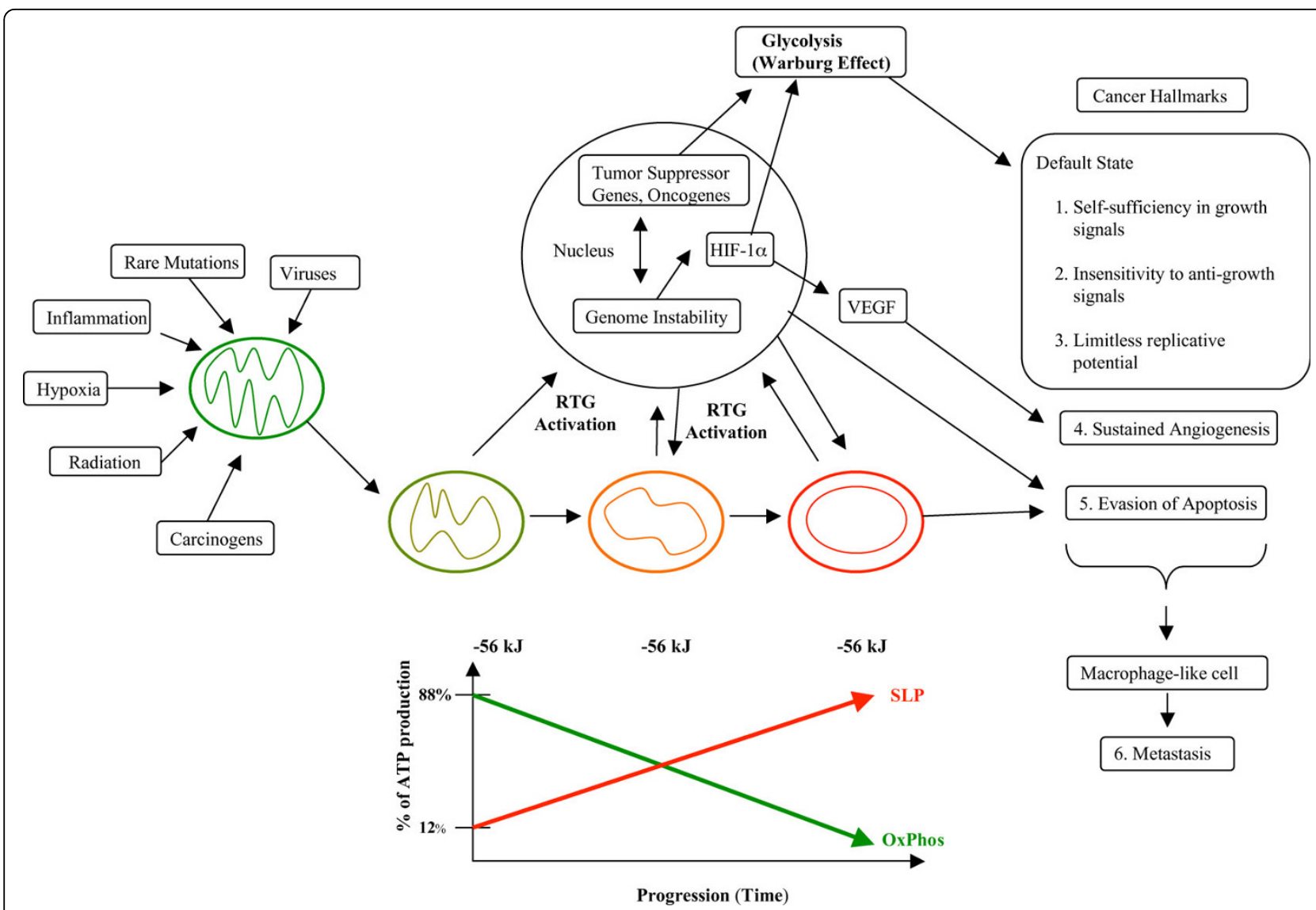

Figure 2 Linking the hallmarks of cancer to impaired energy metabolism. See text for discussion. SLP and OxPhos represent substrate level phosphorylation and oxidative phosphorylation, respectively. The progressive damage to mitochondria during carcinogenesis is illustrated with a change in shape.

greater the dependency on substrate level phosphorylation over time the greater will be the degree of malignancy. Damage to the respiratory capacity of tissue myeloid cells can also produce invasive and metastatic properties according to the macrophage hypothesis of metastasis. This metabolic scenario can account for all major acquired characteristics of cancer to include the Warburg effect.

\section{Implications of the hypothesis to cancer management}

If cancer is primarily a disease of energy metabolism as reviewed here, then rational approaches to cancer management can be found in therapies that specifically target energy metabolism. Although mitochondrial replacement therapy could in principle restore a more normal energy metabolism and differentiated state to tumor cells, it is unlikely that this therapeutic approach would be available in the foreseeable future. However, numerous studies show that dietary energy restriction is a general metabolic therapy that naturally lowers circulating glucose levels and significantly reduces growth and progression of numerous tumor types to include cancers of the mammary, brain, colon, pancreas, lung, and prostate [10,247-256]. The influence of energy restriction on tumor growth, however, can depend on host background and tumor growth site, as energy restriction is effective in reducing the U87 human glioma when grown orthotopically in the brain of immunodeficient SCID mice [175], but not when grown outside the brain in non-obese diabetic SCID mice [257]. Nevertheless, the bulk of evidence indicates that dietary energy restriction can retard the growth rate of many tumors regardless of the specific genetic defects expressed within the tumor.

\section{Targeting Glucose}

Reduced glucose availability will target aerobic glycolysis and the pentose phosphate shunt; pathways required for the survival and proliferation of many types of tumor cells. Dietary energy restriction specifically targets the IGF-1/PI3K/Akt/HIF-1 $\alpha$ signaling pathway, which underlies several cancer hallmarks to include cell proliferation, evasion of apoptosis, and angiogenesis [168,175,176,250,251,254,258-265]. Calorie restriction also causes a simultaneous down-regulation of multiple 
genes and metabolic pathways regulating glycolysis [266-268]. This is important, as enhanced glycolysis is required for the rapid growth and survival of many tumor cells $[21,22]$. In addition, recent findings suggest that a large subset of gliomas have acquired mutations in the TCA cycle gene, isocitrate dehydrogenase (IDH1) [105]. Such mutations are expected to limit the function of the TCA cycle, thus increasing the glycolytic dependence of these tumors. Tumors with these types of mutations could be especially vulnerable to management through dietary energy restriction. Hence, dietary energy or calorie restriction can be considered a broad-spectrum, non-toxic metabolic therapy that inhibits multiple signaling pathways required for progression of malignant tumors regardless of tissue origin.

Besides lowering circulating glucose levels, dietary energy restriction elevates circulating levels of fatty acids and ketone bodies ( $\beta$-hydroxybutyrate and acetoacetate) $[266,269,270]$. Fats and especially ketone bodies can replace glucose as a primary metabolic fuel under calorie restriction. This is a conserved physiological adaptation that evolved to spare protein during periods of starvation [271,272]. Many tumors, however, have abnormalities in the genes and enzymes needed to metabolize ketone bodies for energy [273-275]. A transition from carbohydrate to ketones for energy is a simple way to target energy metabolism in glycolysis-dependent tumor cells while enhancing the metabolic efficiency of normal cells $[276,277]$. The shift from the metabolism of glucose to the metabolism of ketone bodies for energy is due largely to the shift in circulating levels of insulin and glucagon, key hormones that mediate energy metabolism. Insulin, which stimulates glycolysis, is reduced under dietary restriction, while glucagon, which inhibits glycolysis and mobilizes fats, is increased. Glucose reduction not only reduces insulin, but also reduces circulating levels of IGF-1, which is necessary for driving tumor cell metabolism and growth $[168,278]$. Glucocorticoids, which enhance glucagon action and the stress response, are also elevated under dietary energy restriction [261]. The shift in levels of these metabolic hormones would place greater physiological stress on the tumor cells than on normal cells since the tumor cells lack metabolic flexibility due to accumulated genetic mutations [10,15,277].

Inferences that tumor cells have a growth advantage over normal cells are inconsistent with principles of evolutionary biology $[10,277]$. Although viewed as a growth advantage, the dysregulated growth of tumor cells is actually an aberrant phenotype. How can tumor cells that express multiple mutations and mitochondrial abnormalities be more "fit" or "advantaged" than normal cells that possess a flexible genome, normal respiratory capacity, and adaptive versatility? The short answer is that they are not. Normal cells can grow much faster than tumor cells during normal wound repair. Metabolism of ketone bodies and fatty acids for energy requires inner mitochondrial membrane integrity and efficient respiration, which tumor cells largely lack $[10,273,278]$. In contrast to the tumor cells, normal cells evolved to survive extreme shifts in the physiological environment and can readily adapt to fat metabolism when glucose becomes limiting. Glucose transporter expression is higher in mouse brain tumor cells than in neighboring normal cells when circulating glucose levels are high, but the transporter phenotype of these cells becomes reversed under dietary energy restriction [168]. These findings highlight the different responses to energy stress between the metabolically incompetent tumor cells and competent normal cells. Consequently, a shift in energy metabolism from glucose to ketone bodies protects respiratory competent normal cells while targeting the genetically defective and respiratory challenged tumor cells, which depend more heavily on glycolysis than normal cells for survival $[10,278,279]$.

Proof of concept for cancer metabolic therapy was illustrated for the management of malignant astrocytoma in mice, and malignant glioma in children $[273,276,280]$. Prostate and gastric cancer also appears manageable using low carbohydrate ketogenic diets $[252,281,282]$. Recent studies show that dietary energy restriction enhances phosphorylation of adenosine monophosphate kinase (AMPK), which induces apoptosis in glycolytic-dependent astrocytoma cells, but protects normal brain cells from death [283]. This further illustrates the differential response of normal cells and tumor cells to energy stress.

A possible concern is how any therapy, which reduces food intake and body weight, can be recommended to individuals who might be losing body weight because of cancer cachexia. Cancer cachexia generally involves anorexia, weight loss, muscle atrophy, and anemia $[284,285]$. Although some cancer patients could be obese, rapid weight loss from cachexia involving both proteins and fat is a health concern [285]. It is important to recognize that pro-cachexia molecules such as proteolysis-inducing factor are released from the tumor cells into the circulation and contribute to the cachexia phenotype [286,287]. By targeting the glycolytically active tumor cells that produce pro-cachexia molecules, restricted diet therapies can potentially reduce tumor cachexia $[278,287]$. These therapies could be supplemented with omega- 3 fatty acids, which can also reduce the cachexia phenotype [285]. Omega-3 fatty acids from fish oil also have the benefit of maintaining low glucose while elevating ketone levels. Once the tumor becomes managed, individuals can increase caloric consumption to achieve weight gain. 
Metabolic therapies involving calorie restriction should be effective in targeting energy-defective cells within a given tumor, and for managing a broad range of glycolysis-dependent tumors. There are no known drugs that can simultaneously target as many tumorassociated signaling pathways as can calorie restriction [168]. Hence, energy restriction can be a cost-effective adjuvant therapy to traditional chemo- or radiation therapies, which are more toxic, costly, and generally less focused in their therapeutic action, than is dietary energy restriction.

In addition to dietary energy restriction, several small molecules that target aerobic glycolysis are under consideration as novel tumor therapeutics to include 2-deoxyglucose, lonidamine, 3-bromopyruvate, imatinib, oxythiamine, and 6-aminonicotinimide among others [129,288-290]. Toxicity can become an issue, however, as some of these compounds target pathways other than glycolysis or nucleotide synthesis and high dosages are sometimes required to achieve efficacy in vivo. A recent study found significant therapeutic synergy in combining low doses of 2-deoxyglucose with a calorie restricted ketogenic diet for managing malignant astrocytoma in mice [291].

It appears that the therapeutic efficacy of anti-glycolytic cancer drugs could be significantly enhanced when combined with dietary energy restriction. The administration of anti-glycolytic drugs together with energy restricted diets, which lower circulating glucose levels while elevating ketone levels, could act as a powerful double "metabolic punch" for the rapid killing of glycolysis dependent tumor cells. This therapeutic approach could open new avenues in cancer drug development, as many drugs that might have minimal therapeutic efficacy or high toxicity when administered alone could become therapeutically relevant and less toxic when combined with energy restricted diets.

\section{Targeting the microenvironment}

Some tumors behave as wounds that do not heal [292]. Growth factors and cytokines released by fibroblasts and macrophages, cells programmed to heal wounds, can actually provoke chronic inflammation and tumor progression [213,245]. Part of the wound healing process also involves degradation of the extracellular matrix and enhancement of angiogenesis, which further contribute to tumor progression [180,213]. Dietary energy restriction targets inflammation and the signaling pathways involved with driving tumor angiogenesis [168,258,293]. Indeed, calorie restriction is considered a simple and effective therapy for targeting tumor angiogenesis and inflammation [176,250,279]. As calorie or dietary energy restriction is a systemic therapy that simultaneously targets both the tumor cells as well as the tumor microenvironment, this approach can be effective in retarding tumor progression.

\section{Targeting Glutamine}

Although dietary energy restriction and anti-glycolytic cancer drugs will have therapeutic efficacy against many tumors that depend largely on glycolysis and glucose for growth, these therapeutic approaches could be less effective against those tumor cells that depend more heavily on glutamine than on glucose for energy [47,65-67]. Glutamine is a major energy metabolite for many tumor cells and especially for cells of hematopoietic or myeloid lineage $[47,49,294,295]$. This is important as cells of myeloid lineage are considered the origin of many metastatic cancers $[17,190,204,221,230]$. Moreover, glutamine is necessary for the synthesis of those cytokines involved in cancer cachexia including tumor necrosis factor alpha, (TNF- $\alpha$ ) and the interleukins 1 and 6 (IL-1 and -6) $[66,284,295,296]$. This further indicates a metabolic linkage between metastatic cancer and myeloid cells, e.g., macrophages. It therefore becomes important to also consider glutamine targeting for the metabolic management of metastatic cancer.

Glutamine can be deaminated to glutamate and then metabolized to $\alpha$-ketoglutarate, a key metabolite of the TCA cycle $[49,67]$. This occurs either through transamination or through enhanced glutamate dehydrogenase activity depending on the availability of glucose [67]. Besides generating energy through substrate level phosphorylation in the TCA cycle, i.e., transphosphorylation of GTP to ATP, the anapleurotic effect of glutamine can also elevate levels of metabolic substrates, which stimulate glycolysis $[49,66]$. Glutamine metabolism can be targeted in humans using the glutamine binding drug, phenylacetate, or the glutamine analogue DON (6Diazo-5-oxo-L-norleucine) [297]. Toxicity, however, can be an issue in attempts to target glutamine metabolism using DON [130,294]. Recent studies suggest that the green tea polyphenol (EGCG) could target glutamine metabolism by inhibiting glutamate dehydrogenase activity under low glucose conditions [67]. This and other glutamine-targeting strategies could be even more effective when combined with energy restricting diets, which lower glucose levels while elevating ketone bodies. Hence, effective non-toxic targeting of both glucose and glutamine metabolism should be a simple therapeutic approach for the global management of most localized and metastatic cancers.

\section{Implications of the hypothesis to cancer prevention}

If impaired mitochondrial energy metabolism underlies the origin of most cancers as proposed here, then protecting mitochondria from damage becomes a logical and simple approach for preventing cancer. It is well documented that the incidence of cancer can be significantly reduced by avoiding exposure to those agents or conditions that provoke tissue inflammation such as 
smoking, alcohol, carcinogenic chemicals, ionizing radiation, obesity etc $[1,25,298]$. Chronic inflammation, regardless of origin, damages tissue morphogenetic fields that eventually produce neoplastic cells $[123,124,166]$. Part of this tissue damage will involve injury to the mitochondria in the affected cells. The prevention of inflammation and damage to the tissue microenvironment will go far in reducing the incidence of most cancers. Vaccines against some oncogenic viruses can also reduce the incidence of cancers, as these viruses can damage mitochondria in infected tissues. Hence, simply reducing exposure to cancer risk factors, which produce chronic inflammation and mitochondrial damage, will reduce the incidence of at least $80 \%$ of all cancers $[1,25]$. In principle, there are few chronic diseases more easily preventable than cancer.

In addition to avoiding exposure to established cancer risk factors, the metabolism of ketone bodies protects the mitochondria from inflammation and damaging ROS. ROS production increases naturally with age and damages cellular proteins, lipids, and nucleic acids. Accumulation of ROS decreases the efficiency of mitochondrial energy production. The origin of mitochondrial ROS comes largely from the spontaneous reaction of molecular oxygen $\left(\mathrm{O}_{2}\right)$ with the semiquinone radical of coenzyme $\mathrm{Q}, \mathrm{QH}$, to generate the superoxide radical $\mathrm{O}_{2^{-}} \cdot[40,84,299]$. Coenzyme Q is a hydrophobic molecule that resides in the inner mitochondrial membrane and is essential for electron transfer. Ketone body metabolism increases the ratio of the oxidized form to the fully reduced form of coenzyme Q $\left(\mathrm{CoQ} / \mathrm{CoQH}_{2}\right)$ [40]. Oxidation of the coenzyme $\mathrm{Q}$ couple reduces the amount of the semiquinone radical, thus decreasing superoxide production [84].

Since the cytosolic free $\mathrm{NADP}^{+} / \mathrm{NADPH}$ concentration couple is in near equilibrium with the glutathione couple, ketone body metabolism will also increase the reduced form of glutathione thus facilitating destruction of hydrogen peroxide $[10,84,300]$. The reduction of free radicals through ketone body metabolism will therefore reduce tissue inflammation provoked by ROS while enhancing the energy efficiency of mitochondria. Ketone bodies are not only a more efficient metabolic fuel than glucose, but also possess anti-inflammatory potential. Metabolism of ketone bodies for energy will maintain mitochondrial health and efficiency thus reducing the incidence of cancer.

The simplest means of initiating the metabolism of ketone bodies is through dietary energy restriction with adequate nutrition. It is important to emphasize adequate nutrition, as calorie restriction associated with malnutrition can potentially increase cancer incidence [301-303]. Consequently, consumption of foods containing the active groups of respiratory enzymes (iron salts, riboflavin, nicotinamide, and pantothenic acid) could be effective in maintaining health when combined with dietary energy restriction [25]. The lowering of circulating glucose levels through calorie restriction facilitates the uptake and metabolism of ketone bodies for use as an alternative respiratory fuel $[84,273,278]$. The metabolism of ketone bodies increases succinate dehydrogenase activity while enhancing the overall efficiency of energy production through respiration $[304,305]$. In essence, dietary energy restriction and ketone body metabolism delays entropy [270]. As cancer is a disease of accelerated entropy $[8,25]$, dietary energy restriction targets the very essence of the disease.

It is well documented that dietary energy restriction can reduce the incidence of both inherited and acquired cancers in experimental animals [256,258,306-309]. Evidence also indicates that dietary energy restriction can reduce the incidence of several human cancers [310,311]. The implementation of periodic dietary energy restriction, which targets multiple cancer provoking factors, can be a simple and cost effective life-style change that is capable of reducing the incidence of cancer. Dietary energy restriction in rodents, however, is comparable to water only therapeutic fasting or to very low caloric diets (500-600 kcal/day) in humans [270]. In light of this fact, it remains to be determined if members of our species are willing or motivated enough to adopt the life style changes necessary to prevent cancer.

\section{Conclusions}

Evidence is reviewed supporting a general hypothesis that cancer is primarily a disease of energy metabolism. All of the major hallmarks of the disease can be linked to impaired mitochondrial function. In order to maintain viability, tumor cells gradually transition to substrate level phosphorylation using glucose and glutamine as energy substrates. While cancer causing germline mutations are rare, the abundance of somatic genomic abnormalities found in the majority of cancers can arise as a secondary consequence of mitochondrial dysfunction. Once established, somatic genomic instability can contribute to further mitochondrial defects and to the metabolic inflexibility of the tumor cells. Systemic metastasis is the predicted outcome following protracted mitochondrial damage to cells of myeloid origin. Tumor cells of myeloid origin would naturally embody the capacity to exit and enter tissues. Two major conclusions emerge from the hypothesis; first that many cancers can regress if energy intake is restricted and, second, that many cancers can be prevented if energy intake is restricted. Consequently, energy restricted diets combined with drugs targeting glucose and glutamine can provide a rational strategy for the longer-term management and prevention of most cancers. 


\section{Acknowledgements}

This work was supported from NIH grants (NS-055195; CA-102135) and from the Boston College Research expense fund. The authors thank Purna Mukherjee, Michael Kiebish, Roberto Flores, Thomas Chiles, Richard Veech, and Jeff Chuang for critical comments. We also thank the students of BI503 (Erin Wolf, Joseph Bravo, Nicholas Buffin, Gregory Della Penna, Robert Hornung, Michelle Levine, Stephen Lo, Brett Pantera, Toan Phan, John Reed, Jeans Santana, and Andrew Syvertsen) for technical assistance and their attempts to disprove the main hypothesis.

\section{Authors' contributions}

TNS wrote the manuscript. LMS contributed to the general outline of topic presentation, editorial assistance, and to discussion of key issues. Both authors read and approved the final manuscript.

\section{Competing interests}

The authors declare that they have no competing interests.

Received: 15 November 2009

Accepted: 27 January 2010 Published: 27 January 2010

\section{References}

1. Anand P, Kunnumakkara $A B$, Sundaram $C$, Harikumar KB, Tharakan $S T$, Lai OS, Sung B, Aggarwal BB: Cancer is a preventable disease that requires major lifestyle changes. Pharm Res 2008, 25:2097-2116.

2. Bailar JC, Gornik HL: Cancer undefeated. N Engl J Med 1997, 336:1569-1574.

3. Sonnenschein C, Soto AM: Theories of carcinogenesis: an emerging perspective. Semin Cancer Biol 2008, 18:372-377.

4. Baker SG, Kramer BS: Paradoxes in carcinogenesis: new opportunities for research directions. BMC Cancer 2007, 7:151.

5. Soto $\mathrm{AM}$, Sonnenschein $\mathrm{C}$ : The somatic mutation theory of cancer: growing problems with the paradigm?. Bioessays 2004, 26:1097-1107.

6. Hanahan D, Weinberg RA: The hallmarks of cancer. Cell 2000, 100:57-70.

7. Loeb LA: A mutator phenotype in cancer. Cancer Res 2001, 61:3230-3239.

8. Szent-Gyorgyi A: The living state and cancer. Proc Natl Acad Sci USA 1977, 74:2844-2847.

9. Roth DB, Gellert M: New guardians of the genome. Nature 2000, 404:823-825.

10. Seyfried TN, Mukherjee P: Targeting energy metabolism in brain cancer: review and hypothesis. Nutr Metab (Lond) 2005, 2:30.

11. Semenza GL, Artemov D, Bedi A, Bhujwalla Z, Chiles K, Feldser D, Laughner E, Ravi R, Simons J, Taghavi P, Zhong H: 'The metabolism of tumours': 70 years later. Novartis Found Symp 2001, 240:251-260, discussion 260-254.

12. Ristow M: Oxidative metabolism in cancer growth. Curr Opin Clin Nutr Metab Care 2006, 9:339-345.

13. Gatenby RA, Gillies RJ: Why do cancers have high aerobic glycolysis?. Nat Rev Cancer 2004, 4:891-899.

14. Gogvadze V, Orrenius S, Zhivotovsky B: Mitochondria in cancer cells: what is so special about them?. Trends Cell Biol 2008, 18:165-173.

15. Lengauer C, Kinzler KW, Vogelstein B: Genetic instabilities in human cancers. Nature 1998, 396:643-649.

16. Wokolorczyk D, Gliniewicz B, Sikorski A, Zlowocka E, Masojc B, Debniak T, Matyjasik J, Mierzejewski M, Medrek K, Oszutowska D, Suchy J, Gronwald J, Teodorczyk U, Huzarski T, Byrski T, Jakubowska A, Gorski B, Wetering van de T, Walczak S, Narod SA, Lubinski J, Cybulski C: A range of cancers is associated with the rs6983267 marker on chromosome 8. Cancer Res 2008, 68:9982-9986.

17. Nowell PC: Tumor progression: a brief historical perspective. Semin Cancer Biol 2002, 12:261-266.

18. Frezza C, Gottlieb E: Mitochondria in cancer: Not just innocent bystanders. Semin Cancer Biol 2008.

19. Gatenby RA, Gillies RJ: Glycolysis in cancer: a potential target for therapy. Int J Biochem Cell Biol 2007, 39:1358-1366.

20. Heiden Vander MG, Cantley LC, Thompson CB: Understanding the Warburg effect: the metabolic requirements of cell proliferation. Science 2009, 324:1029-1033.

21. Ortega AD, Sanchez-Arago M, Giner-Sanchez D, Sanchez-Cenizo L, Willers I, Cuezva JM: Glucose avidity of carcinomas. Cancer Lett 2009, 276:125-135.

22. Altenberg B, Greulich KO: Genes of glycolysis are ubiquitously overexpressed in 24 cancer classes. Genomics 2004, 84:1014-1020.
23. Warburg O: The Metabolism of Tumours. New York Richard R Smith 1931

24. Warburg O: On the origin of cancer cells. Science 1956, 123:309-314.

25. Warburg O: The prime cause of cancer and prevention - Part 2. Annual meeting of Nobelists at Lindau, Germany 1969http://www.hopeforcancer. com/OxyPlus.htm.

26. Moreno-Sanchez R, Rodriguez-Enriquez S, Saavedra E, Marin-Hernandez A, Gallardo-Perez JC: The bioenergetics of cancer: is glycolysis the main ATP supplier in all tumor cells?. Biofactors 2009, 35:209-225.

27. Bonnet S, Archer SL, Allalunis-Turner J, Haromy A, Beaulieu C, Thompson R, Lee CT, Lopaschuk GD, Puttagunta L, Bonnet S, Harry G, Hashimoto K, Porter CJ, Andrade MA, Thebaud B, Michelakis ED: A mitochondria-K+ channel axis is suppressed in cancer and its normalization promotes apoptosis and inhibits cancer growth. Cancer Cell 2007, 11:37-51.

28. Semenza GL: HIF-1 mediates the Warburg effect in clear cell renal carcinoma. J Bioenerg Biomembr 2007, 39:231-234.

29. Moreno-Sanchez R, Rodriguez-Enriquez S, Marin-Hernandez A, Saavedra E: Energy metabolism in tumor cells. Febs J 2007, 274:1393-1418.

30. Aisenberg AC: The Glycolysis and Respiration of Tumors. New York, Academic Press 1961.

31. Fantin VR, Leder P: Mitochondriotoxic compounds for cancer therapy. Oncogene 2006, 25:4787-4797.

32. Hervouet E, Demont J, Pecina P, Vojtiskova A, Houstek J, Simonnet H, Godinot C: A new role for the von Hippel-Lindau tumor suppressor protein: stimulation of mitochondrial oxidative phosphorylation complex biogenesis. Carcinogenesis 2005, 26:531-539.

33. Weinhouse S: On respiratory impairment in cancer cells. Science 1956, 124:267-269.

34. Weinhouse S: The Warburg hypothesis fifty years later. Z Krebsforsch Klin Onkol Cancer Res Clin Oncol 1976, 87:115-126.

35. Krebs H: Otto Warburg: Cell Physiologist, Biochemist, and Eccentric. Oxford, Clarendon 1981.

36. Kim JW, Dang CV: Cancer's molecular sweet tooth and the Warburg effect. Cancer Res 2006, 66:8927-8930.

37. Hsu PP, Sabatini DM: Cancer cell metabolism: Warburg and beyond. Cell 2008, 134:703-707.

38. Shaw RJ: Glucose metabolism and cancer. Current opinion in cell biology 2006, 18:598-608.

39. Jones RG, Thompson CB: Tumor suppressors and cell metabolism: a recipe for cancer growth. Genes Dev 2009, 23:537-548.

40. Veech RL, Chance B, Kashiwaya Y, Lardy HA, Cahill GF Jr: Ketone bodies, potential therapeutic uses. IUBMB Life 2001, 51:241-247.

41. Kocherginsky N: Acidic lipids, H(+)-ATPases, and mechanism of oxidative phosphorylation. Physico-chemical ideas 2009, 99:20-41.

42. Veech RL, Kashiwaya Y, Gates DN, King MT, Clarke K: The energetics of ion distribution: the origin of the resting electric potential of cells. IUBMB Life 2002, 54:241-252.

43. Veech RL, Lawson JW, Cornell NW, Krebs HA: Cytosolic phosphorylation potential. J Biol Chem 1979, 254:6538-6547.

44. Donnelly M, Scheffler IE: Energy metabolism in respiration-deficient and wild type Chinese hamster fibroblasts in culture. J Cell Physiol 1976, 89:39-51.

45. Baggetto LG: Deviant energetic metabolism of glycolytic cancer cells. Biochimie 1992, 74:959-974

46. Weinberg JM, Venkatachalam MA, Roeser NF, Nissim I: Mitochondrial dysfunction during hypoxia/reoxygenation and its correction by anaerobic metabolism of citric acid cycle intermediates. Proc Natl Acad Sci USA 2000, 97:2826-2831

47. Reitzer LJ, Wice BM, Kennell D: Evidence that glutamine, not sugar, is the major energy source for cultured HeLa cells. J Biol Chem 1979, 254:2669-2676.

48. Schwimmer C, Lefebvre-Legendre L, Rak M, Devin A, Slonimski PP, di Rago JP, Rigoulet M: Increasing mitochondrial substrate-level phosphorylation can rescue respiratory growth of an ATP synthasedeficient yeast. J Biol Chem 2005, 280:30751-30759.

49. DeBerardinis RJ: Is cancer a disease of abnormal cellular metabolism? New angles on an old idea. Genet Med 2008, 10:767-777.

50. Phillips D, Aponte AM, French SA, Chess DJ, Balaban RS: Succinyl-CoA synthetase is a phosphate target for the activation of mitochondrial metabolism. Biochemistry 2009, 48:7140-7149.

51. Wallace DC: Mitochondria and cancer: Warburg addressed. Cold Spring Harb Symp Quant Biol 2005, 70:363-374. 
52. Pedersen PL: Tumor mitochondria and the bioenergetics of cancer cells. Prog Exp Tumor Res 1978, 22:190-274.

53. Wu M, Neilson A, Swift AL, Moran R, Tamagnine J, Parslow D, Armistead S, Lemire K, Orrell J, Teich J, Chomicz S, Ferrick DA: Multiparameter metabolic analysis reveals a close link between attenuated mitochondrial bioenergetic function and enhanced glycolysis dependency in human tumor cells. Am J Physiol Cell Physiol 2007, 292 C125-136.

54. Fantin VR, St-Pierre J, Leder P: Attenuation of LDH-A expression uncovers a link between glycolysis, mitochondrial physiology, and tumor maintenance. Cancer Cell 2006, 9:425-434.

55. Colowick SP: The status of Warburg's theory of glycolysis and respiration in tumors. Quart Rev Biol 1961, 36:273-276.

56. Zu XL, Guppy M: Cancer metabolism: facts, fantasy, and fiction. Biochem Biophys Res Commun 2004, 313:459-465

57. Burk D, Schade AL: On respiratory impairment in cancer cells. Science 1956, 124:270-272.

58. Chance B, Hess B: Spectroscopic evidence of metabolic control. Science 1959, 129:700-708.

59. Samudio I, Fiegl M, Andreeff M: Mitochondrial uncoupling and the Warburg effect: molecular basis for the reprogramming of cancer cell metabolism. Cancer Res 2009, 69:2163-2166.

60. Chen Y, Cairns R, Papandreou I, Koong A, Denko NC: Oxygen consumption can regulate the growth of tumors, a new perspective on the warburg effect. PLoS One 2009, 4:e7033.

61. Ramanathan A, Wang C, Schreiber SL: Perturbational profiling of a cell-line model of tumorigenesis by using metabolic measurements. Proc Natl Acad Sci USA 2005, 102:5992-5997.

62. Mayevsky A: Mitochondrial function and energy metabolism in cancer cells: Past overview and future perspectives. Mitochondrion 2009.

63. van Wijk R, Souren J, Schamhart DH, van Miltenburg JC: Comparative studies of the heat production of different rat hepatoma cells in culture. Cancer Res 1984, 44:671-673.

64. Smith AE, Kenyon DH: A unifying concept of carcinogenesis and its therapeutic implications. Oncology 1973, 27:459-479.

65. Yuneva M: Finding an "Achilles' heel" of cancer: the role of glucose and glutamine metabolism in the survival of transformed cells. Cell Cycle 2008, 7:2083-2089.

66. Deberardinis RJ, Cheng T: Q's next: the diverse functions of glutamine in metabolism, cell biology and cancer. Oncogene 2009.

67. Yang C, Sudderth J, Dang T, Bachoo RG, McDonald JG, Deberardinis RJ: Glioblastoma Cells Require Glutamate Dehydrogenase to Survive Impairments of Glucose Metabolism or Akt Signaling. Cancer Res 2009

68. John AP: Dysfunctional mitochondria, not oxygen insufficiency, cause cancer cells to produce inordinate amounts of lactic acid: the impact of this on the treatment of cancer. Med Hypotheses 2001, 57:429-431.

69. Galluzzi L, Morselli E, Kepp O, Vitale I, Rigoni A, Vacchelli E, Michaud M, Zischka H, Castedo M, Kroemer G: Mitochondrial gateways to cancer. Mol Aspects Med 2009.

70. Foster CS, Spoerri PE, Glees P, Spoerri O: The mode of mitochondrial degeneration in gliomas. Acta Neurochir (Wien) 1978, 43:229-237.

71. Rasmussen AK, Chatterjee A, Rasmussen LJ, Singh KK: Mitochondriamediated nuclear mutator phenotype in Saccharomyces cerevisiae. Nucleic Acids Res 2003, 31:3909-3917.

72. Cuezva JM, Krajewska M, de Heredia ML, Krajewski S, Santamaria G, Kim H, Zapata JM, Marusawa H, Chamorro M, Reed JC: The bioenergetic signature of cancer: a marker of tumor progression. Cancer Res 2002, 62:6674-6681.

73. Kiebish MA, Han X, Cheng H, Chuang JH, Seyfried TN: Cardiolipin and electron transport chain abnormalities in mouse brain tumor mitochondria: Lipidomic evidence supporting the Warburg theory of cancer. J Lipid Res 2008.

74. Arismendi-Morillo GJ, Castellano-Ramirez AV: Ultrastructural mitochondrial pathology in human astrocytic tumors: potentials implications protherapeutics strategies. J Electron Microsc (Tokyo) 2008, 57:33-39.

75. Kiebish MA, $\operatorname{Han} \mathrm{X}$, Cheng $\mathrm{H}$, Seyfried TN: In vitro growth environment produces lipidomic and electron transport chain abnormalities in mitochondria from non-tumorigenic astrocytes and brain tumours. ASN Neuro 2009, 1 .

76. Diaz-Ruiz R, Uribe-Carvajal S, Devin A, Rigoulet M: Tumor cell energy metabolism and its common features with yeast metabolism. Biochim Biophys Acta 2009, 1796:252-265.
77. Crabtree HG: Observations on the carbohydrate metabolism of tumors. Biochem J 1929, 23:536-545.

78. Bellance N, Benard G, Furt F, Begueret H, Smolkova K, Passerieux E, Delage JP, Baste JM, Moreau P, Rossignol R: Bioenergetics of lung tumors: alteration of mitochondrial biogenesis and respiratory capacity. Int J Biochem Cell Biol 2009, 41:2566-2577.

79. Jiang F, Ryan MT, Schlame M, Zhao M, Gu Z, Klingenberg M, Pfanner N, Greenberg ML: Absence of cardiolipin in the crd1 null mutant results in decreased mitochondrial membrane potential and reduced mitochondrial function. J Biol Chem 2000, 275:22387-22394.

80. Claypool SM, Oktay Y, Boontheung P, Loo JA, Koehler CM: Cardiolipin defines the interactome of the major ADP/ATP carrier protein of the mitochondrial inner membrane. J Cell Biol 2008, 182:937-950.

81. Ohtsuka T, Nishijima M, Suzuki K, Akamatsu Y: Mitochondrial dysfunction of a cultured Chinese hamster ovary cell mutant deficient in cardiolipin. J Biol Chem 1993, 268:22914-22919.

82. Chicco AJ, Sparagna GC: Role of cardiolipin alterations in mitochondrial dysfunction and disease. American journal of physiology Cell physiology 2007, 292:C33-44.

83. Schug ZT, Gottlieb E: Cardiolipin acts as a mitochondrial signalling platform to launch apoptosis. Biochim Biophys Acta 2009.

84. Veech RL: The therapeutic implications of ketone bodies: the effects of ketone bodies in pathological conditions: ketosis, ketogenic diet, redox states, insulin resistance, and mitochondrial metabolism. Prostaglandins Leukot Essent Fatty Acids 2004, 70:309-319.

85. Trachootham D, Alexandre J, Huang P: Targeting cancer cells by ROSmediated mechanisms: a radical therapeutic approach?. Nat Rev Drug Discov 2009, 8:579-591.

86. Detmer SA, Chan DC: Functions and dysfunctions of mitochondrial dynamics. Nat Rev Mol Cell Biol 2007, 8:870-879.

87. Acebo $\mathrm{P}$, Giner D, Calvo P, Blanco-Rivero A, Ortega AD, Fernandez PL, Roncador G, Fernandez-Malave E, Chamorro M, Cuezva JM: Cancer abolishes the tissue type-specific differences in the phenotype of energetic metabolism. Transl Oncol 2009, 2:138-145.

88. Unwin RD, Craven RA, Harnden P, Hanrahan S, Totty N, Knowles M, Eardley I, Selby PJ, Banks RE: Proteomic changes in renal cancer and coordinate demonstration of both the glycolytic and mitochondrial aspects of the Warburg effect. Proteomics 2003, 3:1620-1632.

89. Simonnet H, Alazard N, Pfeiffer K, Gallou C, Beroud C, Demont J, Bouvier R, Schagger H, Godinot C: Low mitochondrial respiratory chain content correlates with tumor aggressiveness in renal cell carcinoma. Carcinogenesis 2002, 23:759-768.

90. Roskelley RC, Mayer N, Horwitt BN, Salter WT: Studies in Cancer. Vii. Enzyme Deficiency in Human and Experimental Cancer. J Clin Invest 1943, 22:743-751.

91. Rasnick D, Duesberg PH: How aneuploidy affects metabolic control and causes cancer. Biochem J 1999, 340(Pt 3):621-630.

92. Parsons DW, Jones $S$, Zhang $X$, Lin JC, Leary RJ, Angenendt $P$, Mankoo $P$, Carter H, Siu IM, Gallia GL, Olivi A, McLendon R, Rasheed BA, Keir S, Nikolskaya T, Nikolsky Y, Busam DA, Tekleab H, Diaz LA Jr, Hartigan J, Smith DR, Strausberg RL, Marie SK, Shinjo SM, Yan H, Riggins GJ, Bigner DD, Karchin R, Papadopoulos N, Parmigiani G, Vogelstein B, Velculescu VE, Kinzler KW: An integrated genomic analysis of human glioblastoma multiforme. Science 2008, 321:1807-1812.

93. Jones $S$, Zhang $X$, Parsons DW, Lin JC, Leary RJ, Angenendt P, Mankoo P, Carter H, Kamiyama H, Jimeno A, Hong SM, Fu B, Lin MT, Calhoun ES, Kamiyama M, Walter K, Nikolskaya T, Nikolsky Y, Hartigan J, Smith DR, Hidalgo M, Leach SD, Klein AP, Jaffee EM, Goggins M, Maitra A, lacobuzioDonahue C, Eshleman JR, Kern SE, Hruban RH, Karchin R, Papadopoulos N, Parmigiani G, Vogelstein B, Velculescu VE, Kinzler KW: Core signaling pathways in human pancreatic cancers revealed by global genomic analyses. Science 2008, 321:1801-1806.

94. Pollard PJ, Wortham NC, Tomlinson IP: The TCA cycle and tumorigenesis: the examples of fumarate hydratase and succinate dehydrogenase. Ann Med 2003, 35:632-639.

95. Hao HX, Khalimonchuk O, Schraders M, Dephoure N, Bayley JP, Kunst H, Devilee P, Cremers CW, Schiffman JD, Bentz BG, Gygi SP, Winge DR, Kremer H, Rutter J: SDH5, a Gene Required for Flavination of Succinate Dehydrogenase, Is Mutated in Paraganglioma. Science 2009.

96. Baysal BE, Ferrell RE, Willett-Brozick JE, Lawrence EC, Myssiorek D, Bosch A, Mey van der A, Taschner PE, Rubinstein WS, Myers EN, Richard CW, 
Cornelisse C, Devilee P, Devlin B: Mutations in SDHD, a mitochondrial complex II gene, in hereditary paraganglioma. Science 2000, 287:848-851.

97. Alam NA, Rowan AJ, Wortham NC, Pollard PJ, Mitchell M, Tyrer JP, Barclay E, Calonje E, Manek S, Adams SJ, Bowers PW, Burrows NP, Charles-Holmes R, Cook L, Daly BM, Ford GP, Fuller LC, Hadfield-Jones SE, Hardwick N, Highet AS, Keefe M, MacDonald-Hull SP, Potts ED, Crone M, Wilkinson S, Camacho-Martinez F, Jablonska S, Ratnavel R, MacDonald A, Mann RJ, Grice K, Guillet G, Lewis-Jones MS, McGrath H, Seukeran DC, Morrison PJ, Fleming S, Rahman S, Kelsell D, Leigh I, Olpin S, Tomlinson IP: Genetic and functional analyses of $\mathrm{FH}$ mutations in multiple cutaneous and uterine leiomyomatosis, hereditary leiomyomatosis and renal cancer, and fumarate hydratase deficiency. Hum Mol Genet 2003, 12:1241-1252.

98. Favier J, Briere JJ, Burnichon N, Riviere J, Vescovo L, Benit P, GiscosDouriez I, De Reynies A, Bertherat J, Badoual C, Tissier F, Amar L, Libe R, Plouin PF, Jeunemaitre $X$, Rustin P, Gimenez-Roqueplo AP: The warburg effect is genetically determined in inherited pheochromocytomas. PLOS One 2009, 4:e7094

99. Malkin D, Li FP, Strong LC, Fraumeni JF Jr, Nelson CE, Kim DH, Kassel J, Gryka MA, Bischoff FZ, Tainsky MA, et al: Germ line p53 mutations in a familial syndrome of breast cancer, sarcomas, and other neoplasms. Science 1990, 250:1233-1238.

100. Yokota J: Tumor progression and metastasis. Carcinogenesis 2000, 21:497-503.

101. Duesberg P, Rasnick D, Li R, Winters L, Rausch C, Hehlmann R: How aneuploidy may cause cancer and genetic instability. Anticancer Res 1999, 19:4887-4906.

102. Kruse JP, Gu W: Modes of p53 regulation. Cell 2009, 137:609-622

103. Olovnikov IA, Kravchenko JE, Chumakov PM: Homeostatic functions of the p53 tumor suppressor: regulation of energy metabolism and antioxidant defense. Semin Cancer Biol 2009, 19:32-41.

104. Sonnenschein C, Soto AM: Somatic mutation theory of carcinogenesis: why it should be dropped and replaced. Mol Carcinog 2000, 29:205-211.

105. Dang L, White DW, Gross S, Bennett BD, Bittinger MA, Driggers EM, Fantin VR, Jang HG, Jin S, Keenan MC, Marks KM, Prins RM, Ward PS, Yen KE, Liau LM, Rabinowitz JD, Cantley LC, Thompson CB, Heiden Vander MG, Su SM: Cancer-associated IDH1 mutations produce 2-hydroxyglutarate. Nature 2009.

106. Traven A, Wong JM, Xu D, Sopta M, Ingles CJ: Interorganellar communication. Altered nuclear gene expression profiles in a yeast mitochondrial dna mutant. J Biol Chem 2001, 276:4020-4027.

107. Veatch JR, McMurray MA, Nelson ZW, Gottschling DE: Mitochondrial dysfunction leads to nuclear genome instability via an iron-sulfur cluster defect. Cell 2009, 137:1247-1258.

108. Jazwinski SM: The retrograde response links metabolism with stress responses, chromatin-dependent gene activation, and genome stability in yeast aging. Gene 2005, 354:22-27.

109. Erol A: Retrograde regulation due to mitochondrial dysfunction may be an important mechanism for carcinogenesis. Med Hypotheses 2005, 65:525-529.

110. Butow RA, Avadhani NG: Mitochondrial signaling: the retrograde response. Mol Cell 2004, 14:1-15.

111. Amuthan G, Biswas G, Ananadatheerthavarada HK, Vijayasarathy C, Shephard HM, Avadhani NG: Mitochondrial stress-induced calcium signaling, phenotypic changes and invasive behavior in human lung carcinoma A549 cells. Oncogene 2002, 21:7839-7849.

112. Miceli MV, Jazwinski SM: Common and cell type-specific responses of human cells to mitochondrial dysfunction. Exp Cell Res 2005, 302:270-280.

113. Singh KK, Kulawiec M, Still I, Desouki MM, Geradts J, Matsui S: Intergenomic cross talk between mitochondria and the nucleus plays an important role in tumorigenesis. Gene 2005, 354:140-146.

114. Liu Z, Butow RA: Mitochondrial retrograde signaling. Annu Rev Genet 2006, 40:159-185.

115. Miceli MV, Jazwinski SM: Nuclear gene expression changes due to mitochondrial dysfunction in ARPE-19 cells: implications for age-related macular degeneration. Invest Ophthalmol Vis Sci 2005, 46:1765-1773.

116. Kulawiec M, Ayyasamy V, Singh KK: p53 regulates mtDNA copy number and mitocheckpoint pathway. J Carcinog 2009, 8:8.

117. Kulawiec M, Safina A, Desouki MM, Still I, Matsui SI, Bakin A, Singh KK: Tumorigenic transformation of human breast epithelial cells induced by mitochondrial DNA depletion. Cancer Biol Ther 2008, 7.
118. Wolfman JC, Planchon SM, Liao J, Wolfman A: Structural and functional consequences of c-N-Ras constitutively associated with intact mitochondria. Biochim Biophys Acta 2006, 1763:1108-1124.

119. Borghouts C, Benguria A, Wawryn J, Jazwinski SM: Rtg2 protein links metabolism and genome stability in yeast longevity. Genetics 2004, 166:765-777.

120. Simbula G, Glascott PA Jr, Akita S, Hoek JB, Farber JL: Two mechanisms by which ATP depletion potentiates induction of the mitochondrial permeability transition. Am J Physiol 1997, 273:C479-488.

121. Arnould T, Vankoningsloo S, Renard P, Houbion A, Ninane N, Demazy C, Remacle J, Raes M: CREB activation induced by mitochondrial dysfunction is a new signaling pathway that impairs cell proliferation. Embo J 2002, 21:53-63.

122. Whitfield JF: Calcium, calcium-sensing receptor and colon cancer. Cancer Lett 2009, 275:9-16.

123. Coussens LM, Werb Z: Inflammation and cancer. Nature 2002, 420:860-867.

124. Colotta F, Allavena P, Sica A, Garlanda C, Mantovani A: Cancer-related inflammation, the seventh hallmark of cancer: links to genetic instability. Carcinogenesis 2009, 30:1073-1081.

125. Amuthan G, Biswas G, Zhang SY, Klein-Szanto A, Vijayasarathy C, Avadhani NG: Mitochondria-to-nucleus stress signaling induces phenotypic changes, tumor progression and cell invasion. Embo J 2001, 20:1910-1920.

126. Biswas $G$, Guha M, Avadhani NG: Mitochondria-to-nucleus stress signaling in mammalian cells: nature of nuclear gene targets, transcription regulation, and induced resistance to apoptosis. Gene 2005, 354:132-139.

127. Semenza GL: Oxygen-dependent regulation of mitochondrial respiration by hypoxia-inducible factor 1. Biochem J 2007, 405:1-9.

128. Dang CV, Semenza GL: Oncogenic alterations of metabolism. Trends Biochem Sci 1999, 24:68-72.

129. Denko NC: Hypoxia, HIF1 and glucose metabolism in the solid tumour. Nat Rev Cancer 2008, 8:705-713.

130. Tennant DA, Duran RV, Boulahbel H, Gottlieb E: Metabolic transformation in cancer. Carcinogenesis 2009, 30:1269-1280.

131. King A, Selak MA, Gottlieb E: Succinate dehydrogenase and fumarate hydratase: linking mitochondrial dysfunction and cancer. Oncogene 2006, 25:4675-4682.

132. Rius J, Guma M, Schachtrup C, Akassoglou K, Zinkernagel AS, Nizet V, Johnson RS, Haddad GG, Karin M: NF-kappaB links innate immunity to the hypoxic response through transcriptional regulation of HIF-1alpha. Nature 2008, 453:807-811.

133. Zhang L, Li L, Liu H, Prabhakaran K, Zhang X, Borowitz JL, Isom GE: HIF1alpha activation by a redox-sensitive pathway mediates cyanideinduced BNIP3 upregulation and mitochondrial-dependent cell death. Free Radic Biol Med 2007, 43:117-127.

134. Haeberle HA, Durrstein C, Rosenberger P, Hosakote YM, Kuhlicke J, Kempf VA, Garofalo RP, Eltzschig HK: Oxygen-independent stabilization of hypoxia inducible factor (HIF)-1 during RSV infection. PLoS One 2008, 3: e3352.

135. Moon EJ, Jeong CH, Jeong JW, Kim KR, Yu DY, Murakami S, Kim CW, Kim KW: Hepatitis B virus $x$ protein induces angiogenesis by stabilizing hypoxia-inducible factor-1alpha. Faseb J 2004, 18:382-384.

136. Dang CV, Le A, Gao P: MYC-Induced Cancer Cell Energy Metabolism and Therapeutic Opportunities. Clin Cancer Res 2009.

137. Kolodner RD, Putnam CD, Myung K: Maintenance of genome stability in Saccharomyces cerevisiae. Science 2002, 297:552-557.

138. Delsite R, Kachhap S, Anbazhagan R, Gabrielson E, Singh KK: Nuclear genes involved in mitochondria-to-nucleus communication in breast cancer cells. Mol Cancer 2002, 1:6.

139. Evans AR, Limp-Foster M, Kelley MR: Going APE over ref-1. Mutat Res 2000, 461:83-108.

140. Ma Y, Bai RK, Trieu R, Wong L: Mitochondrial dysfunction in human breast cancer cells and their transmitochondrial cybrids. Biochim Biophys Acta 2010, 1797:29-37.

141. Lebedeva MA, Eaton JS, Shadel GS: Loss of p53 causes mitochondrial DNA depletion and altered mitochondrial reactive oxygen species homeostasis. Biochim Biophys Acta 2009, 1787:328-334.

142. Holley AK, St Clair DK: Watching the watcher: regulation of $\mathrm{p} 53$ by mitochondria. Future Oncol 2009, 5:117-130. 
143. Busso CS, Iwakuma T, Izumi T: Ubiquitination of mammalian AP endonuclease (APE1) regulated by the $\mathrm{p} 53-\mathrm{MDM} 2$ signaling pathway. Oncogene 2009, 28:1616-1625.

144. Burhans WC, Heintz NH: The cell cycle is a redox cycle: Linking phasespecific targets to cell fate. Free Radic Biol Med 2009.

145. Whitaker M: Calcium microdomains and cell cycle control. Cell Calcium 2006, 40:585-592.

146. Liu Y, Malureanu L, Jeganathan KB, Tran DD, Lindquist LD, van Deursen JM, Bram RJ: CAML loss causes anaphase failure and chromosome missegregation. Cell Cycle 2009, 8:940-949.

147. Marx J: Cell biology. Do centrosome abnormalities lead to cancer?. Science 2001, 292:426-429.

148. Chang DC, Meng C: A localized elevation of cytosolic free calcium is associated with cytokinesis in the zebrafish embryo. J Cell Biol 1995, 131:1539-1545.

149. Salmon ED, Segall RR: Calcium-labile mitotic spindles isolated from sea urchin eggs (Lytechinus variegatus). J Cell Biol 1980, 86:355-365.

150. Anghileri $\mathrm{L}$ : Warburg's cancer theory revisited: a fundamentally new approach. Arch Geschwulstforsch 1983, 53:1-8.

151. Fosslien E: Cancer morphogenesis: role of mitochondrial failure. Ann Clin Lab Sci 2008, 38:307-329.

152. Parkin DM: The global health burden of infection-associated cancers in the year 2002. Int J Cancer 2006, 118:3030-3044.

153. Koike $\mathrm{K}$ : Hepatitis $\mathrm{B}$ virus $\mathrm{X}$ gene is implicated in liver carcinogenesis. Cancer Lett 2009

154. Clippinger AJ, Bouchard MJ: Hepatitis B virus HBx protein localizes to mitochondria in primary rat hepatocytes and modulates mitochondrial membrane potential. J Virol 2008, 82:6798-6811.

155. D'Agostino DM, Bernardi P, Chieco-Bianchi L, Ciminale V: Mitochondria as functional targets of proteins coded by human tumor viruses. Adv Cancer Res 2005, 94:87-142.

156. Koura M, Isaka H, Yoshida MC, Tosu M, Sekiguchi T: Suppression of tumorigenicity in interspecific reconstituted cells and cybrids. Gann 1982, 73:574-580.

157. Israel BA, Schaeffer WI: Cytoplasmic suppression of malignancy. In Vitro Cell Dev Biol 1987, 23:627-632.

158. Howell AN, Sager R: Tumorigenicity and its suppression in cybrids of mouse and Chinese hamster cell lines. Proc Natl Acad Sci USA 1978, 75:2358-2362.

159. Petros JA, Baumann AK, Ruiz-Pesini E, Amin MB, Sun CQ, Hall J, Lim S, Issa MM, Flanders WD, Hosseini SH, Marshall FF, Wallace DC: mtDNA mutations increase tumorigenicity in prostate cancer. Proc Natl Acad SCi USA 2005, 102:719-724.

160. Hochedlinger K, Blelloch R, Brennan C, Yamada Y, Kim M, Chin L, Jaenisch R: Reprogramming of a melanoma genome by nuclear transplantation. Genes Dev 2004, 18:1875-1885.

161. Li L, Connelly MC, Wetmore C, Curran T, Morgan Jl: Mouse embryos cloned from brain tumors. Cancer Res 2003, 63:2733-2736.

162. McKinnell RG, Deggins BA, Labat DD: Transplantation of pluripotential nuclei from triploid frog tumors. Science 1969, 165:394-396.

163. Harris $H$ : The analysis of malignancy by cell fusion: the position in 1988. Cancer Res 1988, 48:3302-3306.

164. Kroemer G, Pouyssegur J: Tumor cell metabolism: cancer's Achilles' heel. Cancer Cell 2008, 13:472-482

165. Tzachanis D, Boussiotis VA: Tob, a member of the APRO family, regulates immunological quiescence and tumor suppression. Cell Cycle 2009, 8:1019-1025.

166. Sonnenschein C, Soto AM: The Society of Cells: Cancer and the Control of Cell Proliferation. New York, Springer-Verlag 1999.

167. Godinot C, de Laplanche E, Hervouet E, Simonnet H: Actuality of Warburg's views in our understanding of renal cancer metabolism. $J$ Bioenerg Biomembr 2007, 39:235-241.

168. Marsh J, Mukherjee P, Seyfried TN: Akt-dependent proapoptotic effects of dietary restriction on late-stage management of a phosphatase and tensin homologue/tuberous sclerosis complex 2-deficient mouse astrocytoma. Clin Cancer Res 2008, 14:7751-7762.

169. Gao P, Tchernyshyov I, Chang TC, Lee YS, Kita K, Ochi T, Zeller Kl, De Marzo AM, Van Eyk JE, Mendell JT, Dang CV: c-Myc suppression of miR$23 \mathrm{a} / \mathrm{b}$ enhances mitochondrial glutaminase expression and glutamine metabolism. Nature 2009, 458:762-765.
170. Wise DR, DeBerardinis RJ, Mancuso A, Sayed N, Zhang XY, Pfeiffer HK, Nissim I, Daikhin E, Yudkoff M, McMahon SB, Thompson CB: Myc regulates a transcriptional program that stimulates mitochondrial glutaminolysis and leads to glutamine addiction. Proc Natl Acad Sci USA 2008, 105:18782-18787.

171. Bagheri S, Nosrati M, Li S, Fong S, Torabian S, Rangel J, Moore DH, Federman S, Laposa RR, Baehner FL, Sagebiel RW, Cleaver JE, Haqq C, Debs RJ, Blackburn EH, Kashani-Sabet M: Genes and pathways downstream of telomerase in melanoma metastasis. Proc Natl Acad Sci USA 2006, 103:11306-11311.

172. Saretzki G: Telomerase, mitochondria and oxidative stress. Exp Gerontol 2009, 44:485-492.

173. Santos JH, Meyer JN, Van Houten B: Mitochondrial localization of telomerase as a determinant for hydrogen peroxide-induced mitochondrial DNA damage and apoptosis. Hum Mol Genet 2006, 15:1757-1768.

174. Ahmed S, Passos JF, Birket MJ, Beckmann T, Brings S, Peters H, BirchMachin MA, von Zglinicki T, Saretzki G: Telomerase does not counteract telomere shortening but protects mitochondrial function under oxidative stress. J Cell Sci 2008, 121:1046-1053.

175. Mukherjee $P$, Abate LE, Seyfried TN: Antiangiogenic and proapoptotic effects of dietary restriction on experimental mouse and human brain tumors. Clin Cancer Res 2004, 10:5622-5629.

176. Mukherjee P, El-Abbadi MM, Kasperzyk JL, Ranes MK, Seyfried TN: Dietary restriction reduces angiogenesis and growth in an orthotopic mouse brain tumour model. Br J Cancer 2002, 86:1615-1621.

177. Iruela-Arispe ML, Dvorak HF: Angiogenesis: a dynamic balance of stimulators and inhibitors. Thromb Haemost 1997, 78:672-677.

178. Folkman J: The role of angiogenesis in tumor growth. Semin Cancer Biol 1992, 3:65-71

179. Folkman J: Incipient angiogenesis. J Natl Cancer Inst 2000, 92:94-95.

180. Greenberg Jl, Cheresh DA: VEGF as an inhibitor of tumor vessel maturation: implications for cancer therapy. Expert Opin Biol Ther 2009, 9:1347-1356.

181. Claffey KP, Brown LF, del Aguila LF, Tognazzi K, Yeo KT, Manseau EJ, Dvorak HF: Expression of vascular permeability factor/vascular endothelial growth factor by melanoma cells increases tumor growth, angiogenesis, and experimental metastasis. Cancer Res 1996, 56:172-181.

182. Ferrara N, Gerber HP, LeCouter J: The biology of VEGF and its receptors. Nat Med 2003, 9:669-676.

183. Bos R, van Diest PJ, de Jong JS, Groep van der P, Valk van der P, Wall van der E: Hypoxia-inducible factor-1alpha is associated with angiogenesis, and expression of bFGF, PDGF-BB, and EGFR in invasive breast cancer. Histopathology 2005, 46:31-36.

184. Tarin D: Comparisons of metastases in different organs: biological and clinical implications. Clin Cancer Res 2008, 14:1923-1925.

185. Bacac M, Stamenkovic I: Metastatic cancer cell. Annu Rev Pathol 2008 3:221-247

186. Duffy MJ, McGowan PM, Gallagher WM: Cancer invasion and metastasis: changing views. J Pathol 2008, 214:283-293.

187. Steeg PS: Tumor metastasis: mechanistic insights and clinical challenges. Nat Med 2006, 12:895-904.

188. Chambers AF, Groom AC, MacDonald IC: Dissemination and growth of cancer cells in metastatic sites. Nat Rev Cancer 2002, 2:563-572.

189. Fidler IJ: The pathogenesis of cancer metastasis: the 'seed and soil' hypothesis revisited. Nat Rev Cancer 2003, 3:453-458.

190. Huysentruyt LC, Shelton LM, Seyfried TN: Influence of methotrexate and cisplatin on tumor progression and survival in the VM mouse model of systemic metastatic cancer. Int J Cancer 2010, 126:65-72.

191. Khanna C, Hunter K: Modeling metastasis in vivo. Carcinogenesis 2005, 26:513-523.

192. Steeg PS: Heterogeneity of drug target expression among metastatic lesions: lessons from a breast cancer autopsy program. Clin Cancer Res 2008, 14:3643-3645.

193. Pawelek JM: Cancer-cell fusion with migratory bone-marrow-derived cells as an explanation for metastasis: new therapeutic paradigms. Future Oncol 2008, 4:449-452

194. Kalluri R: EMT: when epithelial cells decide to become mesenchymal-like cells. J Clin Invest 2009, 119:1417-1419.

195. Nowell PC: The clonal evolution of tumor cell populations. Science 1976, 194:23-28 
196. Fearon ER, Vogelstein B: A genetic model for colorectal tumorigenesis. Cell 1990, 61:759-767.

197. Carro MS, Lim WK, Alvarez MJ, Bollo RJ, Zhao X, Snyder EY, Sulman EP, Anne SL, Doetsch F, Colman H, Lasorella A, Aldape K, Califano A, lavarone A: The transcriptional network for mesenchymal transformation of brain tumours. Nature 1999.

198. Hart IR: New evidence for tumour embolism as a mode of metastasis. $J$ Pathol 2009, 219:275-276.

199. Garber K: Epithelial-to-mesenchymal transition is important to metastasis, but questions remain. J Natl Cancer Inst 2008, 100:232-233.

200. Lu X, Kang Y: Cell Fusion as a Hidden Force in Tumor Progression. Cancer Res 2009.

201. Munzarova M, Lauerova L, Kovarik J, Rejthar A, Brezina V, Kellnerova R, Kovarik A: Fusion-induced malignancy?. A preliminary study. (a challenge to today's common wisdom). Neoplasma 1992, 39:79-86

202. Ruff MR, Pert CB: Small cell carcinoma of the lung: macrophage-specific antigens suggest hemopoietic stem cell origin. Science 1984, 225:1034-1036.

203. Fais S: Cannibalism: a way to feed on metastatic tumors. Cancer Lett 2007, 258:155-164

204. Huysentruyt LC, Mukherjee P, Banerjee D, Shelton LM, Seyfried TN: Metastatic cancer cells with macrophage properties: evidence from a new murine tumor model. Int J Cancer 2008, 123:73-84.

205. Munzarova M, Kovarik J: Is cancer a macrophage-mediated autoaggressive disease?. Lancet 1987, 1:952-954.

206. Pawelek JM, Chakraborty AK: Fusion of tumour cells with bone marrowderived cells: a unifying explanation for metastasis. Nat Rev Cancer 2008, 8:377-386

207. Pawelek JM: Tumour-cell fusion as a source of myeloid traits in cancer. Lancet Oncol 2005, 6:988-993.

208. Psaila B, Lyden D: The metastatic niche: adapting the foreign soil. Nat Rev Cancer 2009, 9:285-293.

209. Munzarova M, Lauerova L, Capkova J: Are advanced malignant melanoma cells hybrids between melanocytes and macrophages?. Melanoma Res 1992, 2:127-129.

210. Lugini L, Matarrese $P$, Tinari $A$, Lozupone F, Federici $C$, lessi $E$, Gentile $M$, Luciani F, Parmiani G, Rivoltini L, Malorni W, Fais S: Cannibalism of live lymphocytes by human metastatic but not primary melanoma cells. Cancer Res 2006, 66:3629-3638.

211. Willenbring $H$, Bailey AS, Foster M, Akkari Y, Dorrell C, Olson S, Finegold M, Fleming WH, Grompe M: Myelomonocytic cells are sufficient for therapeutic cell fusion in liver. Nat Med 2004, 10:744-748.

212. Glinsky GV, Berezovska O, Glinskii AB: Microarray analysis identifies a death-from-cancer signature predicting therapy failure in patients with multiple types of cancer. J Clin Invest 2005, 115:1503-1521.

213. Joyce JA, Pollard JW: Microenvironmental regulation of metastasis. Nat Rev Cancer 2009, 9:239-252.

214. Gordon S: Development and distribution of mononuclear phagocytes: Relevance to inflammation. Inflammation: Basic Principles and Clinical Correlates New York: Lippincott Williams \& WilkinsSnyderman JIGaR 1999, 35-48.

215. Lewis CE, Pollard JW: Distinct role of macrophages in different tumor microenvironments. Cancer Res 2006, 66:605-612.

216. Pollard JW: Macrophages define the invasive microenvironment in breast cancer. J Leukoc Biol 2008, 84:623-630.

217. Scherer HJ: A critical review: The pathology of cerebral gliomas. J Neurol Neuropsychiat 1940, 3:147-177.

218. Leenstra S, Das PK, Troost D, de Boer OJ, Bosch DA: Human malignant astrocytes express macrophage phenotype. J Neuroimmunol 1995 56:17-25.

219. Youness E, Barlogie B, Ahearn M, Trujillo JM: Tumor cell phagocytosis. Its occurrence in a patient with medulloblastoma. Arch Pathol Lab Med 1980, 104:651-653.

220. Kumar PV, Hosseinzadeh M, Bedayat GR: Cytologic findings of medulloblastoma in crush smears. Acta Cytol 2001, 45:542-546.

221. Shabo I, Olsson H, Sun XF, Svanvik J: Expression of the macrophage antigen CD163 in rectal cancer cells is associated with early local recurrence and reduced survival time. Int J Cancer 2009, 125:1826-1831.

222. Handerson T, Camp R, Harigopal M, Rimm D, Pawelek J: Beta1,6-branched oligosaccharides are increased in lymph node metastases and predict poor outcome in breast carcinoma. Clin Cancer Res 2005, 11:2969-2973.
223. Abodief WT, Dey P, Al-Hattab O: Cell cannibalism in ductal carcinoma of breast. Cytopathology 2006, 17:304-305.

224. Marin-Padilla M: Erythrophagocytosis by epithelial cells of a breast carcinoma. Cancer 1977, 39:1085-1089.

225. Spivak JL: Phagocytic tumour cells. Scand J Haematol 1973, 11:253-256.

226. Ruff MR, Farrar WL, Pert CB: Interferon gamma and granulocyte/ macrophage colony-stimulating factor inhibit growth and induce antigens characteristic of myeloid differentiation in small-cell lung cancer cell lines. Proc Natl Acad Sci USA 1986, 83:6613-6617.

227. Molad Y, Stark P, Prokocimer M, Joshua H, Pinkhas J, Sidi Y: Hemophagocytosis by small cell lung carcinoma. Am J Hematol 1991, 36:154-156.

228. Falini B, Bucciarelli E, Grignani F, Martelli MF: Erythrophagocytosis by undifferentiated lung carcinoma cells. Cancer 1980, 1140-1145.

229. DeSimone PA, East R, Powell RD Jr: Phagocytic tumor cell activity in oat cell carcinoma of the lung. Hum Pathol 1980, 11:535-539.

230. Pawelek JM, Chakraborty AK: The cancer cell-leukocyte fusion theory of metastasis. Adv Cancer Res 2008, 101:397-444.

231. Rachkovsky M, Sodi S, Chakraborty A, Avissar Y, Bolognia J, McNiff JM, Platt J, Bermudes D, Pawelek J: Melanoma $\times$ macrophage hybrids with enhanced metastatic potential. Clin Exp Metastasis 1998, 16:299-312.

232. Monteagudo C, Jorda E, Carda C, Illueca C, Peydro A, Llombart-Bosch A: Erythrophagocytic tumour cells in melanoma and squamous cell carcinoma of the skin. Histopathology 1997, 31:367-373.

233. Breier F, Feldmann R, Fellenz C, Neuhold N, Gschnait F: Primary invasive signet-ring cell melanoma. J Cutan Pathol 1999, 26:533-536.

234. Lazar D, Taban S, Dema A, Cornianu M, Goldis A, Ratiu I, Sporea I: Gastric cancer: the correlation between the clinicopathological factors and patients' survival (I). Rom J Morphol Embryol 2009, 50:41-50.

235. Sung CO, Seo JW, Kim KM, Do IG, Kim SW, Park CK: Clinical significance of signet-ring cells in colorectal mucinous adenocarcinoma. Mod Pathol 2008, 21:1533-1541.

236. Moonda A, Fatteh S: Metastatic colorectal carcinoma: an unusual presentation. J Cutan Pathol 2009, 36:64-66

237. Schorlemmer HU, Bosslet K, Kern HF, Sedlacek HH: Similarities in function between pancreatic tumor cells and macrophages and their inhibition by murine monoclonal antibodies. Behring Inst Mitt 1988, 240-264.

238. Khayyata S, Basturk O, Adsay NV: Invasive micropapillary carcinomas of the ampullo-pancreatobiliary region and their association with tumorinfiltrating neutrophils. Mod Pathol 2005, 18:1504-1511.

239. Kojima S, Sekine H, Fukui I, Ohshima H: Clinical significance of "cannibalism" in urinary cytology of bladder cancer. Acta Cytol 1998, 42:1365-1369.

240. Chetty R, Cvijan D: Giant (bizarre) cell variant of renal carcinoma. Histopathology 1997, 30:585-587.

241. Yasunaga M, Ohishi Y, Nishimura I, Tamiya S, Iwasa A, Takagi E, Inoue T, Yahata $\mathrm{H}$, Kobayashi $\mathrm{H}$, Wake $\mathrm{N}$, Tsuneyoshi M: Ovarian undifferentiated carcinoma resembling giant cell carcinoma of the lung. Pathol Int 2008, 58:244-248.

242. Lee H, Sodek KL, Hwang Q, Brown TJ, Ringuette M, Sodek J: Phagocytosis of collagen by fibroblasts and invasive cancer cells is mediated by MT1MMP. Biochem Soc Trans 2007, 35:704-706.

243. Tsoi WC, Feng CS: Hemophagocytosis by rhabdomyosarcoma cells in bone marrow. Am J Hematol 1997, 54:340-342.

244. Etcubanas E, Peiper S, Stass S, Green A: Rhabdomyosarcoma, presenting as disseminated malignancy from an unknown primary site: a retrospective study of ten pediatric cases. Med Pediatr Oncol 1989, 17:39-44.

245. Seyfried TN: Perspectives on brain tumor formation involving macrophages, glia, and neural stem cells. Perspect Biol Med 2001, 44:263-282.

246. Kim SY, Roh JL, Yeo NK, Kim JS, Lee JH, Choi SH, Nam SY: Combined 18Ffluorodeoxyglucose-positron emission tomography and computed tomography as a primary screening method for detecting second primary cancers and distant metastases in patients with head and neck cancer. Ann Oncol 2007, 18:1698-1703.

247. Hursting SD, Kari FW: The anti-carcinogenic effects of dietary restriction: mechanisms and future directions. Mutat Res 1999, 443:235-249.

248. Jose DG, Good RA: Quantitative effects of nutritional protein and calorie deficiency upon immune responses to tumors in mice. Cancer Res 1973, 33:807-812. 
249. Wheatley KE, Williams EA, Smith NC, Dillard A, Park EY, Nunez NP, Hursting SD, Lane MA: Low-carbohydrate diet versus caloric restriction: effects on weight loss, hormones, and colon tumor growth in obese mice. Nutr Cancer 2008, 60:61-68.

250. Mukherjee P, Sotnikov AV, Mangian HJ, Zhou JR, Visek WJ, Clinton SK: Energy intake and prostate tumor growth, angiogenesis, and vascular endothelial growth factor expression. J Natl Cancer Inst 1999, 91:512-523.

251. Kari FW, Dunn SE, French JE, Barrett JC: Roles for insulin-like growth factor-1 in mediating the anti-carcinogenic effects of caloric restriction. $J$ Nutr Health Aging 1999, 3:92-101.

252. Mavropoulos JC, Buschemeyer WC, Tewari AK, Rokhfeld D, Pollak M, Zhao Y, Febbo PG, Cohen P, Hwang D, Devi G, Demark-Wahnefried W, Westman EC, Peterson BL, Pizzo SV, Freedland SJ: The effects of varying dietary carbohydrate and fat content on survival in a murine LNCaP prostate cancer xenograft model. Cancer Prev Res (Phila Pa) 2009, 2:557-565.

253. Bonorden MJ, Rogozina OP, Kluczny CM, Grossmann ME, Grambsch PL, Grande JP, Perkins S, Lokshin A, Cleary MP: Intermittent calorie restriction delays prostate tumor detection and increases survival time in TRAMP mice. Nutr Cancer 2009, 61:265-275.

254. Thompson HJ, McGinley JN, Spoelstra NS, Jiang W, Zhu Z, Wolfe P: Effect of dietary energy restriction on vascular density during mammary carcinogenesis. Cancer Res 2004, 64:5643-5650.

255. Kritchevsky D: Caloric restriction and experimental carcinogenesis. Toxicol Sci 1999, 52:13-16.

256. Tannenbaum A: Nutrition and cancer. Physiopathology of Cancer NY: Paul B. HoberHomburger F 1959, 517-562.

257. Kalaany NY, Sabatini DM: Tumours with PI3K activation are resistant to dietary restriction. Nature 2009, 458:725-731.

258. Hursting SD, Smith SM, Lashinger LM, Harvey AE, Perkins SN: Calories and carcinogenesis: lessons learned from 30 years of calorie restriction research. Carcinogenesis 2010, 31:83-89.

259. Pelicano H, Xu RH, Du M, Feng L, Sasaki R, Carew JS, Hu Y, Ramdas L, Hu L, Keating MJ, Zhang W, Plunkett W, Huang P: Mitochondrial respiration defects in cancer cells cause activation of Akt survival pathway through a redox-mediated mechanism. J Cell Biol 2006, 175:913-923.

260. Young CD, Anderson SM: Sugar and fat - that's where it's at: metabolic changes in tumors. Breast Cancer Res 2008, 10:202.

261. Thompson HJ, Jiang W, Zhu Z: Mechanisms by which energy restriction inhibits carcinogenesis. Adv Exp Med Biol 1999, 470:77-84.

262. Thompson HJ, Zhu Z, Jiang W: Dietary Energy Restriction in Breast Cancer Prevention. Journal of mammary gland biology and neoplasia 2003, 8:133-142.

263. Mukherjee $P$, Zhau J-R, Sotnikov AV, Clinton SK: Dietary and nutritional modulation of tumor angiogenesis. Antiangiogenic Agents in Cancer Therapy Totowa, NJ: Humana PressTeicher BA 1999, 237-261.

264. Thompson HJ, Zhu Z, Jiang W: Identification of the apoptosis activation cascade induced in mammary carcinomas by energy restriction. Cancer Res 2004, 64:1541-1545.

265. Zhu Z, Jiang W, McGinley J, Wolfe P, Thompson HJ: Effects of dietary energy repletion and IGF-1 infusion on the inhibition of mammary carcinogenesis by dietary energy restriction. Molecular carcinogenesis 2005, 42:170-176.

266. Hagopian K, Ramsey JJ, Weindruch R: Influence of age and caloric restriction on liver glycolytic enzyme activities and metabolite concentrations in mice. Exp Gerontol 2003, 38:253-266.

267. Lee CK, Klopp RG, Weindruch R, Prolla TA: Gene expression profile of aging and its retardation by caloric restriction. Science 1999, 285:1390-1393.

268. Lee CK, Weindruch R, Prolla TA: Gene-expression profile of the ageing brain in mice. Nat Genet 2000, 25:294-297.

269. Mantis JG, Centeno NA, Todorova MT, McGowan R, Seyfried TN: Management of multifactorial idiopathic epilepsy in EL mice with caloric restriction and the ketogenic diet: role of glucose and ketone bodies. Nutr Metab (Lond) 2004, 1:11.

270. Mahoney LB, Denny CA, Seyfried TN: Caloric restriction in C57BL/6J mice mimics therapeutic fasting in humans. Lipids Health Dis 2006, 5:13.

271. Cahill GF Jr: Starvation in man. N Engl J Med 1970, 282:668-675.

272. Cahill GF Jr, Veech RL: Ketoacids? Good medicine?. Trans Am Clin Climatol Assoc 2003, 114:149-161, discussion 162-143.
273. Zhou W, Mukherjee P, Kiebish MA, Markis WT, Mantis JG, Seyfried TN: The calorically restricted ketogenic diet, an effective alternative therapy for malignant brain cancer. Nutr Metab (Lond) 2007, 4:5.

274. Fredericks M, Ramsey RB: 3-Oxo acid coenzyme A transferase activity in brain and tumors of the nervous system. J Neurochem 1978, 31:1529-1531.

275. Tisdale MJ, Brennan RA: Loss of acetoacetate coenzyme A transferase activity in tumours of peripheral tissues. Br J Cancer 1983, 47:293-297.

276. Seyfried NT, Kiebish M, Mukherjee P: Targeting energy metabolism in brain cancer with restricted diets. Glioblastoma: Molecular Mechanisms of Pathogenesis and Current Therapeutic Strategies New York: SpringerRay S 2010, 341-363.

277. Seyfried TN, Kiebish M, Mukherjee P, Marsh J: Targeting energy metabolism in brain cancer with calorically restricted ketogenic diets. Epilepsia 2008, 49(Suppl 8):114-116.

278. Seyfried TN, Sanderson TM, El-Abbadi MM, McGowan R, Mukherjee P: Role of glucose and ketone bodies in the metabolic control of experimental brain cancer. Br J Cancer 2003, 89:1375-1382.

279. Seyfried TN, Mukherjee P: Anti-Angiogenic and Pro-Apoptotic Effects of Dietary Restriction in Experimental Brain Cancer: Role of Glucose and Ketone Bodies. Integration/Interaction of Oncologic Growth. Cancer Growth and Progression New York: Kluwer AcademicMeadows GG 2005, 15:259-270.

280. Nebeling LC, Miraldi F, Shurin SB, Lerner E: Effects of a ketogenic diet on tumor metabolism and nutritional status in pediatric oncology patients: two case reports. J Am Coll Nutr 1995, 14:202-208.

281. Otto C, Kaemmerer U, Illert B, Muehling B, Pfetzer N, Wittig R, Voelker HU, Thiede A, Coy JF: Growth of human gastric cancer cells in nude mice is delayed by a ketogenic diet supplemented with omega- 3 fatty acids and medium-chain triglycerides. BMC Cancer 2008, 8:122.

282. Mavropoulos JC, Isaacs WB, Pizzo SV, Freedland SJ: Is there a role for a low-carbohydrate ketogenic diet in the management of prostate cancer?. Urology 2006, 68:15-18.

283. Mukherjee P, Mulrooney TJ, Marsh J, Blair D, Chiles TC, Seyfried TN: Differential effects of energy stress on AMPK phosphorylation and apoptosis in experimental brain tumor and normal brain. Mol Cancer 2008, 7:37.

284. Argiles JM, Moore-Carrasco R, Fuster G, Busquets S, Lopez-Soriano FJ: Cancer cachexia: the molecular mechanisms. Int J Biochem Cell Biol 2003, 35:405-409.

285. Tisdale MJ: Cancer anorexia and cachexia. Nutrition 2001, 17:438-442.

286. Todorov PT, Wyke SM, Tisdale MJ: Identification and characterization of a membrane receptor for proteolysis-inducing factor on skeletal muscle. Cancer Res 2007, 67:11419-11427.

287. Tisdale MJ: Biology of cachexia. J Natl Cancer Inst 1997, 89:1763-1773.

288. Lopez-Lazaro M: The warburg effect: why and how do cancer cells activate glycolysis in the presence of oxygen?. Anticancer Agents Med Chem 2008, 8:305-312.

289. Rodriguez-Enriquez S, Marin-Hernandez A, Gallardo-Perez JC, CarrenoFuentes L, Moreno-Sanchez R: Targeting of cancer energy metabolism. Mol Nutr Food Res 2009, 53:29-48.

290. Pelicano H, Martin DS, Xu RH, Huang P: Glycolysis inhibition for anticancer treatment. Oncogene 2006, 25:4633-4646.

291. Marsh J, Mukherjee P, Seyfried TN: Drug/diet synergy for managing malignant astrocytoma in mice: 2-deoxy-D-glucose and the restricted ketogenic diet. Nutr Metab (Lond) 2008, 5:33.

292. Dvorak HF: Tumors: wounds that do not heal. Similarities between tumor stroma generation and wound healing. N Engl J Med 1986, 315:1650-1659.

293. Dong W, Selgrade MK, Gilmour IM, Lange RW, Park P, Luster MI, Kari FW Altered alveolar macrophage function in calorie-restricted rats. Am J Respir Cell Mol Biol 1998, 19:462-469.

294. Medina MA: Glutamine and cancer. J Nutr 2001, 131:2539S-2542S, discussion 2550S-2531S.

295. Newsholme P: Why is L-glutamine metabolism important to cells of the immune system in health, postinjury, surgery or infection?. J Nutr 2001, 131:2515S-2522S, discussion 2523S-2514S.

296. Tijerina AJ: The biochemical basis of metabolism in cancer cachexia. Dimens Crit Care Nurs 2004, 23:237-243.

297. Piscitelli SC, Thibault A, Figg WD, Tompkins A, Headlee D, Lieberman R, Samid D, Myers CE: Disposition of phenylbutyrate and its metabolites, phenylacetate and phenylacetylglutamine. J Clin Pharmacol 1995, 35:368-373. 
298. American Cancer Society: Cancer Facts \& Figures 2009. American Cancer Society, Atlanta 2009, 68.

299. Chance B, Sies H, Boveris A: Hydroperoxide metabolism in mammalian organs. Physiol Rev 1979, 59:527-605.

300. Ziegler DR, Ribeiro LC, Hagenn M, Siqueira IR, Araujo E, Torres IL, Gottfried C, Netto CA, Goncalves CA: Ketogenic diet increases glutathione peroxidase activity in rat hippocampus. Neurochem Res 2003, 28:1793-1797.

301. Elias SG, Peeters PH, Grobbee DE, van Noord PA: Breast cancer risk after caloric restriction during the 1944-1945 Dutch famine. J Natl Cancer Inst 2004, 96:539-546.

302. Hursting SD, Forman MR: Cancer risk from extreme stressors: lessons from European Jewish survivors of World War II. J Natl Cancer Inst 2009, 101:1436-1437.

303. Qiao YL, Dawsey SM, Kamangar F, Fan JH, Abnet CC, Sun XD, Johnson LL, Gail MH, Dong ZW, Yu B, Mark SD, Taylor PR: Total and cancer mortality after supplementation with vitamins and minerals: follow-up of the Linxian General Population Nutrition Intervention Trial. J Natl Cancer Inst 2009, 101:507-518

304. Balietti M, Fattoretti P, Giorgetti B, Casoli T, Di Stefano G, Solazzi M, Platano D, Aicardi G, Bertoni-Freddari C: A ketogenic diet increases succinic dehydrogenase activity in aging cardiomyocytes. Ann N Y Acad Sci 2009, 1171:377-384.

305. Sato K, Kashiwaya Y, Keon CA, Tsuchiya N, King MT, Radda GK, Chance B, Clarke K, Veech RL: Insulin, ketone bodies, and mitochondrial energy transduction. Faseb J 1995, 9:651-658.

306. Cleary MP, Jacobson MK, Phillips FC, Getzin SC, Grande JP, Maihle NJ: Weight-cycling decreases incidence and increases latency of mammary tumors to a greater extent than does chronic caloric restriction in mouse mammary tumor virus-transforming growth factor-alpha female mice. Cancer Epidemiol Biomarkers Prev 2002, 11:836-843.

307. Kritchevsky D: Fundamentals of nutrition: applications to cancer research Nutritional Oncology Boston: Academic PressHeber D, Blackburn GL, Go VLW 1999, 5-10.

308. Kritchevsky D: Caloric restriction and experimental mammary carcinogenesis. Breast Cancer Res Treat 1997, 46:161-167.

309. Hopper BD, Przybyszewski J, Chen HW, Hammer KD, Birt DF: Effect of ultraviolet $\mathrm{B}$ radiation on activator protein 1 constituent proteins and modulation by dietary energy restriction in $\mathrm{SKH}-1$ mouse skin. $\mathrm{Mol}$ Carcinog 2009, 48:843-852.

310. Steinbach G, Heymsfield S, Olansen NE, Tighe A, Holt PR: Effect of caloric restriction on colonic proliferation in obese persons: implications for colon cancer prevention. Cancer Res 1994, 54:1194-1197.

311. Albanes D: Caloric intake, body weight, and cancer: a review. Nutr Cancer 1987, 9:199-217.

doi:10.1186/1743-7075-7-7

Cite this article as: Seyfried and Shelton: Cancer as a metabolic disease. Nutrition \& Metabolism 2010 7:7.

\section{Submit your next manuscript to BioMed Central and take full advantage of:}

- Convenient online submission

- Thorough peer review

- No space constraints or color figure charges

- Immediate publication on acceptance

- Inclusion in PubMed, CAS, Scopus and Google Scholar

- Research which is freely available for redistribution

Submit your manuscript at www.biomedcentral.com/submit
Ciomed Central 